\title{
Combining a coupled FTIR-EGA system and in situ DRIFTS for studying soil organic matter in arable soils
}

\author{
M. S. Demyan ${ }^{1}$, F. Rasche ${ }^{1}$, M. Schütt ${ }^{1}{ }^{*}$, N. Smirnova ${ }^{2,3}$, E. Schulz ${ }^{4}$, and G. Cadisch ${ }^{1}$ \\ ${ }^{1}$ Institute of Plant Production and Agroecology in the Tropics and Subtropics, Universität Hohenheim, 70593 Stuttgart, \\ Germany \\ ${ }^{2}$ Institute of Crop Science, Universität Hohenheim, 70593 Stuttgart, Germany \\ ${ }^{3}$ Institute of Soil Science and Agrochemistry, Siberian Branch of Russian Academy of Science, 630099 Novosibirsk, Russia \\ ${ }^{4}$ Department of Soil Ecology, Helmholz Centre for Environmental Research-UFZ, 06120 Leipzig-Halle, Germany \\ *now at: Department of Soil Ecology, University of Bayreuth, 95448 Bayreuth, Germany
}

Correspondence to: G. Cadisch (cadisch@uni-hohenheim.de)

Received: 28 August 2012 - Published in Biogeosciences Discuss.: 1 November 2012

Revised: 4 March 2013 - Accepted: 22 March 2013 - Published: 2 May 2013

\begin{abstract}
An optimized spectroscopic method combining quantitative evolved gas analysis via Fourier transform infrared spectroscopy (FTIR-EGA) in combination with a qualitative in situ thermal reaction monitoring via diffuse reflectance Fourier transform infrared spectroscopy (in situ $T$ DRIFTS) is being proposed to rapidly characterize soil organic matter (SOM) to study its dynamics and stability. A thermal reaction chamber coupled with an infrared gas cell was used to study the pattern of thermal evolution of carbon dioxide $\left(\mathrm{CO}_{2}\right)$ in order to relate evolved gas (i.e., $\left.\mathrm{CO}_{2}\right)$ to different qualities of SOM. Soil samples were taken from three different arable sites in Germany: (i) the Static Fertilization Experiment, Bad Lauchstädt (Chernozem), from treatments of farmyard manure (FYM), mineral fertilizer (NPK), their combination (FYM + NPK) and control without fertilizer inputs; (ii) Kraichgau; and (iii) Swabian Alb (Cambisols) areas, Southwest Germany. The two latter soils were further fractionated into particulate organic matter (POM), sand and stable aggregates $(\mathrm{Sa}+A)$, silt and clay $(\mathrm{Si}+\mathrm{C})$, and $\mathrm{NaOCl}$ oxidized $\mathrm{Si}+\mathrm{C}$ (rSOC) to gain $\mathrm{OM}$ of different inferred stabilities; respiration was measured from fresh soil samples incubated at $20^{\circ} \mathrm{C}$ and $50 \%$ water holding capacity for 490 days. A variable long path length gas cell was used to record the mid-infrared absorbance intensity of $\mathrm{CO}_{2}(2400$ to $2200 \mathrm{~cm}^{-1}$ ) being evolved during soil heating from 25 to $700{ }^{\circ} \mathrm{C}$ with a heating rate of $68^{\circ} \mathrm{C} \mathrm{min}^{-1}$ and holding time of $10 \mathrm{~min}$ at $700^{\circ} \mathrm{C}$. Separately, the heating chamber was placed in a diffuse reflectance chamber (DRIFTS) for mea-
\end{abstract}

suring the mid-infrared absorbance of the soil sample during heating. Thermal stability of the bulk soils and fractions was measured via the temperature of maximum $\mathrm{CO}_{2}$ evolution $\left(\mathrm{CO}_{2 \max }\right)$.

Results indicated that the FYM + NPK and FYM treatments of the Chernozem soils had a lower $\mathrm{CO}_{2 \max }$ as compared to both NPK and CON treatments. On average, $\mathrm{CO}_{2_{\max }}$ of the Chernozem was much higher $\left(447^{\circ} \mathrm{C}\right)$ as compared to the Cambisol sites (Kraichgau $392^{\circ} \mathrm{C}$; Swabian Alb $384^{\circ} \mathrm{C}$ ). The POM fraction had the highest $\mathrm{CO}_{2_{\max }}\left(477^{\circ} \mathrm{C}\right)$, while rSOC had a first peak at $265^{\circ} \mathrm{C}$ at both sites and a second peak at $392^{\circ} \mathrm{C}$ for the Swabian $\mathrm{Alb}$ and $482^{\circ} \mathrm{C}$ for the Kraichgau. The $\mathrm{CO}_{2 \text { max }}$ increased after 490 day incubation, while the $\mathrm{C}$ lost during incubation was derived from the whole temperature range but a relatively higher proportion from 200 to $350^{\circ} \mathrm{C}$. In situ $T$ DRIFTS measurements indicated decreases in vibrational intensities in the order of $\mathrm{C}$ $\mathrm{OH}=$ unknown $\mathrm{C}$ vibration $<\mathrm{C}-\mathrm{H}<-\mathrm{COO} / \mathrm{C}=\mathrm{C}<\mathrm{C}=\mathrm{C}$ with increasing temperature, but interpretation of vibrational changes was complicated by changes in the spectra (i.e., overall vibrational intensity increased with temperature increase) of the sample during heating. The relative quality changes and corresponding temperatures shown by the in situ $_{T}$ DRIFTS measurements enabled the fitting of four components or peaks to the evolved $\mathrm{CO}_{2}$ thermogram from the FTIR-EGA measurements. This gave a semi-quantitative measure of the quality of evolved $\mathrm{C}$ during the heating experiment, lending more evidence that different qualities of 
SOM are being evolved at different temperatures from 200 to $700{ }^{\circ} \mathrm{C}$. The $\mathrm{CO}_{2_{\max }}$ was influenced by long-term FYM input and also after 490 days of laboratory incubation, indicating that this measurement is an indicator for the relative overall SOM stability. The combination of FTIR-EGA and in situ ${ }_{T}$ DRIFTS allows for a quantitative and qualitative monitoring of thermal reactions of SOM, revealing its relative stability, and provides a sound basis for a peak fitting procedure for assigning proportions of evolved $\mathrm{CO}_{2}$ to different thermal stability components.

\section{Introduction}

Various thermal analytical methods have been explored to study the quantity of soil organic matter (SOM) (Gaál et al., 1994) and its quality (Lopez-Capel et al., 2005), the basic hypothesis being that more labile OM such as carbon (C) associated with microbial biomass or light fraction $\mathrm{C}$ would also be thermally degraded at lower temperatures due to the lower activation energy needed to break the associated bonds, and that more stable compounds would evolve at higher temperatures. Thermal degradation of organic molecules is affected by the arrangement of the molecules in the larger macromolecule and likewise influenced by interactions with mineral surfaces (Blumstein, 1965). These biochemical characteristics are also the basic factors which influence the stabilization of OM in soils (von Lützow et al., 2008). Further, organo-mineral interactions such as ligand exchange, cation ion bridging, and complexation are influenced by clay as well as $\mathrm{Fe}$ - and $\mathrm{Al}$-oxide content and type of soil (von Lützow et al., 2008).

Traditional thermal analytical techniques relied on weight loss (i.e., thermal gravimetric analysis (TGA)), energy changes (differential scanning calorimetry (DSC)), or differential thermal weight loss (DTA) between a sample and a reference material (Siewert, 2004; Leinweber et al., 1992). Different land uses (e.g., grassland, arable, fallow) and different SOM fractions (e.g., light free and inter-aggregate $\mathrm{OM}$ ) have been shown to affect the distribution of weight losses during heating treatments (Lopez-Capel et al., 2005), where it was inferred that weight losses at lower temperatures were related to labile SOM and at higher temperature more stabile SOM was degraded. The TGA/DSC/DTA methods have the drawback that the thermal decomposition of SOM may be difficult to infer due to additional reactions in the same temperature range (Gaál et al., 1994), such as loss of absorbed or interlayer water up to $250^{\circ} \mathrm{C}$ and from 400 to $700^{\circ} \mathrm{C}$ with crystallization and dehydroxylation reactions (Pansu and Gautheyrou, 2006). Isotope measurements ex post facto of different thermal treatments have been used to determine the age or contribution of maize residues to SOM after conversion from winter wheat. Dorodnikov et al. $(2007,2008)$ found that SOM turnover times, as calculated via ${ }^{13} \mathrm{C}$ enrichment from free air carbon enrichment (FACE) experiments, did not increase with increasing temperature treatment, although $\mathrm{C}$ evolved at temperatures $>480^{\circ} \mathrm{C}$ was slightly less bioavailable compared to $\mathrm{C}$ evolved at temperatures $<480^{\circ} \mathrm{C}$. Likewise, Helfrich et al. (2010) did not find a significant increase in recent maize-derived SOM in a $>1.8 \mathrm{~g} \mathrm{~cm}^{-3}$ fraction as measured by ${ }^{13} \mathrm{C}$ dating after a $\mathrm{C} 3$ to $\mathrm{C} 4$ vegetation conversion with increasing heating treatments up to $500^{\circ} \mathrm{C}$.

Although these studies cast doubt on the use of thermal analytical approaches as an indicator of SOM stability, several factors may have affected the results: (i) it was hypothesized that younger SOM would be thermally decomposed at lower temperatures, which may not be the case anymore if the light fraction has been removed and the remaining sample had undergone microbial mediated transformations; (ii) it is not well understood what changes a soil sample undergoes after being exposed to a thermal treatment and then cooled to room temperature to be analyzed for isotope composition; (iii) very slow heating rates, as in the case of Dorodnikov et al. $(2008,2007)$ of $2{ }^{\circ} \mathrm{Cmin}^{-1}$, may shift thermal reactions to significantly lower temperatures (Fernández et al., 2011); and (iv) these slow heating rates may possibly lead to increased char formation, as has been shown during combustion of cellulose (Baldry et al., 1988). Hence, an improved method to directly quantify thermal decomposition products and their quality would greatly advance the investigation of SOM via thermal analysis.

To avoid the aforementioned drawbacks of TGA/DTG and ex post facto analysis, on-line analyses such as FTIR-EGA (Fourier transform infrared-evolved gas analysis) (Plante et al., 2009) and in situ $T$ DRIFTS (in situ monitoring of thermal reactions via diffuse reflectance Fourier transform infrared spectroscopy) (Murakami, et al., 1997) were developed for monitoring thermal reactions of SOM. An online method provides the direct measurement of the combustion/decomposition products of thermal degradation of $\mathrm{OM}$ and has been used in conjunction with TG/DSC for studying SOM (Fernández et al., 2012). FTIR-EGA has been used extensively for the rapid quantification of gaseous reaction products such as $\mathrm{CO}_{2}$, carbon monoxide, water, aliphatics and others for the analysis of lignite, chars of coal and spruce wood (Haselsteiner et al., 2011), and inorganic compounds (e.g., calcium carbonate, barium chloride, etc.; Mittleman, 1990). This method relies on the vibrational frequencies of polar gas molecules in the mid-infrared range from 4000 to $400 \mathrm{~cm}^{-1}$ and it is usually the case that combustion products can be quantitatively determined by integrating the wavenumbers of the gas of interest (e.g., $\mathrm{CO}_{2}$ at 2400 to $2200 \mathrm{~cm}^{-1}$ ) and creating a calibration curve using a known standard (e.g., sodium bicarbonate) (Court and Sephton, 2009; Toops et al., 2005). The in situ ${ }_{T}$ DRIFTS method, on the other hand, allows observations of the changes in vibrational intensities at wavenumbers of interest of a sample during heating (Toops et al., 2005). Hence, combining FTIR-EGA and in $\operatorname{situ}_{T}$ DRIFTS has the potential for the 
Table 1. Study site characteristics.

\begin{tabular}{|c|c|c|c|c|c|c|c|}
\hline Study site & Location & $\mathrm{MAP}^{*} / \mathrm{mm}$ & $\mathrm{MAT}^{*} /{ }^{\circ} \mathrm{C}$ & Soil* & Elevation/m a.s.1.* & $\mathrm{pH}$ & Clay $/ \%$ \\
\hline Bad Lauchstädt & $51^{\circ} 24^{\prime} \mathrm{N}, 11^{\circ} 53^{\prime} \mathrm{E}$ & 483 & 8.8 & Haplic Chernozem & 113 & 6.6 & 21 \\
\hline Kraichgau & $48^{\circ} 55.7^{\prime} \mathrm{N}, 8^{\circ} 42.2^{\prime} \mathrm{E}$ & 780 & 9.1 & Cambisol/Regosol & 322 & 6.7 & 18 \\
\hline Swabian Alb & $48^{\circ} 31.7^{\prime} \mathrm{N}, 9^{\circ} 46.2^{\prime} \mathrm{E}$ & 962 & 6.7 & Cambisol & 686 & 6.5 & 38 \\
\hline
\end{tabular}

* $\mathrm{MAP}=$ mean annual precipitation, MAT $=$ mean annual temperature, soil $=$ FAO classification, $\mathrm{m}$ a.s.l. $=$ meters above sea level.

rapid characterization of SOM based on the properties of the evolved gas profile (i.e., peak temperature, distribution of evolved gas) and the changes in vibrational intensity of midinfrared wavenumbers during heating. In addition to quantifying the total $\mathrm{C}$ amount in a soil sample, by optimizing the combustion conditions the distribution and peak temperature may be related to different chemical and or physical traits. This could then be linked to changes in vibrational frequencies of the soil at different temperatures during in situ $\mathrm{u}_{T}$ DRIFTS measurements to unravel qualitative changes in the types of compounds undergoing thermal degradation.

The objectives of this study were to (i) develop improved experimental techniques of FTIR-EGA and in situ ${ }_{T}$ DRIFTS systems for analyzing SOM across the range of $\mathrm{C}$ contents and stability found in bulk soil and SOM fractions; and (ii) to use these techniques to characterize SOM of different stabilities, treatments, and microbial decomposition status. The hypothesis was that the characteristics of thermal $\mathrm{CO}_{2}$ evolution (i.e., temperature of peak $\mathrm{CO}_{2}$ evolution, changes in low temperature $\mathrm{CO}_{2}$ evolution versus higher temperature $\mathrm{CO}_{2}$ evolution) are affected by different qualities of SOM. Soils or fractions which are more enriched in labile compounds (e.g., farmyard manure treated soil, POM) will have lower thermal stability as compared with soils or fractions which are more enriched in stable compounds (e.g., soil with long history of low residue return after harvest, silt + clay fraction, von Lützow et al., 2007; or a chemically resistant fraction, Zimmermann et al., 2007a). The third objective was to develop an innovative approach to combine the use of FTIREGA and in $\operatorname{situ}_{T}$ DRIFTS to provide a theoretical molecular based framework for deconvolution of different components of the evolved gas thermogram.

\section{Materials and methods}

\subsection{Organic compounds for experimental testing}

Pure, reagent grade glucose (anhydrous, BDH Chemicals Ltd, Poole, UK), xylan (Sigma-Aldrich Chemie, Munich, Germany), and tannic acid (Carl Roth $\mathrm{GmbH}$, Karlsruhe, Germany) were compared to gain initial information on thermally evolved $\mathrm{CO}_{2}$ of different organic substances in the absence of any mineral influence. These substances were chosen as they vary in their chemical structure, ranging from a simple sugar in glucose to the more complex polyphenol type structure of tannic acid, and to test the effect of a dilution with preheated quartz sand $(1: 100)$ on $\mathrm{CO}_{2}$ evolution to optimize combustion conditions.

\subsection{Soils}

Soil samples were from three different sites in Germany. The first site was the Static Fertilization Experiment, Bad Lauchstädt, Germany $\left(51^{\circ} 24^{\prime} \mathrm{N}, 11^{\circ} 53^{\prime} \mathrm{E}\right)$. Archive soil samples were taken from the years 1956, 1992, and 2004 of the treatments of farmyard manure (FYM, $30 \mathrm{tha}^{-1} \mathrm{ev}-$ ery second year), and NPK (mineral) fertilizer (123, 30 and $30 \mathrm{~kg} \mathrm{ha}^{-1} \mathrm{yr}^{-1} \mathrm{~N}, \mathrm{P}$ and $\mathrm{K}$, respectively), combination of both (FYM + NPK, $30 \mathrm{tha}^{-1}$ farmyard manure every second year and 103,6 and $25 \mathrm{~kg} \mathrm{ha}^{-1} \mathrm{yr}^{-1} \mathrm{~N}, \mathrm{P}$ and $\mathrm{K}$, respectively, as mineral fertilizers), and a control (CON) to examine how long-term fertilizer treatments affect SOM properties and thermal characteristics of the bulk soil. The experiment has been running since 1902 under a rotation of winter wheat, potatoes, spring barley, and sugar beets. Soil samples were taken in the fall following harvest of winter wheat from a depth of 0 to $30 \mathrm{~cm}$. The soils were classified as Chernozems (IUSS Working Group WRB, 2007). Bulk mineralogy $(<2 \mathrm{~mm})$ is predominantly quartz with lesser amounts of feldspars and micas (Dreibrodt et al., 2002). More information about the experiment can be found in Körschens et al. (1994) and Table 1 . The second study site $\left(48^{\circ} 55.7^{\prime} \mathrm{N}\right.$, $8^{\circ} 42.2^{\prime}$ E) was in the vicinity of Pforzheim, Germany, in the Kraichgau region, which is characterized by loess parent material and intensive agriculture. Soils sampled were classified as Cambisols (IUSS Working Group WRB, 2007) with bulk mineralogy a mixture of quartz, feldspars, and micas. The third site $\left(48^{\circ} 31.7^{\prime} \mathrm{N}, 9^{\circ} 46.2^{\prime} \mathrm{E}\right)$ was near the village of Nellingen, Germany, in the Swabian Alb. The Swabian Alb soils were formed from limestone residuum and also classified as Cambisols (IUSS Working Group WRB, 2007) with a similar mineralogy as the Kraichgau soil. The crop rotation in the fields of both areas typically consists of winter wheat, maize, and oilseed rape. In both the Kraichgau and Swabian Alb sites, two fields were selected with three plots each with a subplot sampled in the vegetation (winter wheat and maize in the Kraichgau, winter wheat and oil seed rape in the Swabian Alb) and a bare fallow subplot which was kept clear of vegetation during the experiment by hand pulling and periodic spot spraying of glyphosate. The 
fallow plots were used to investigate the turnover of SOM without fresh organic inputs such as roots, aboveground crop residues, and manure/slurry. Soil samples were taken one month after the establishment of the bare fallow subplots and in adjacent vegetated subplots at the end of May to beginning of June 2009. Soil samples for fractionation (Kraichgau and Swabian Alb) and thermal analysis (all three sites) were air-dried and made to pass a $2 \mathrm{~mm}$ sieve. Visible roots and plant residues were removed prior to analysis. The mean annual precipitation and elevation gradients, from lowest to highest, are Bad Lauchstädt (483 mm), Kraichgau (780 mm), and Swabian Alb (962 mm) (Table 1). Mean annual temperature is nearly the same in the Kraichgau and Bad Lauchstädt sites ( 9.1 and $8.8^{\circ} \mathrm{C}$, respectively), but more than two degrees lower in the Swabian Alb $\left(6.7^{\circ} \mathrm{C}\right)$. The clay percentage was highest in soils of the Swabian Alb site (38\%) and lowest in those of the Kraichgau site (18\%).

\subsection{Fractionation}

The soil fractionation method was modified from Zimmermann et al. (2007b). Briefly, $30 \mathrm{~g}$ of $<2 \mathrm{~mm}$ soil was made up to $150 \mathrm{~mL}$ with deionized water and sonified for two minutes at $30 \mathrm{~J} \mathrm{~s}^{-1}$. The mixture was poured onto a $63 \mu \mathrm{m}$ sieve and gently sieved until water passing through the sieve was clear. The $<63 \mu \mathrm{m}$ portion was collected and dried at $40^{\circ} \mathrm{C}$ overnight to yield the silt and clay $(\mathrm{Si}+\mathrm{C})$ fraction. Before drying the bulk, moist $\mathrm{Si}+\mathrm{C}$ fraction, $1 \mathrm{~mL}$ of 0.01 $\mathrm{M}$ calcium chloride solution for flocculation was added to a $20 \mathrm{~mL}$ subsample of the suspension and centrifuged for $15 \mathrm{~min}$ at $3000 \times g$. The clear supernatant was taken as extractible OC. The fraction remaining on the $63 \mu \mathrm{m}$ sieve was transferred to a $10 \mathrm{~mL}$ test tube and $5 \mathrm{~mL}$ of $1.8 \mathrm{~g} \mathrm{~cm}^{-3}$ density sodium polytungstate (SPT) solution was added, mixed, and centrifuged for $15 \mathrm{~min}$ at $3000 \times \mathrm{g}$. The fraction floating on top of the SPT was poured off and $4 \mathrm{~mL}$ SPT was added to the remaining fraction, mixed, and centrifuged again to remove any remaining light fraction material. The floating material yielded the particulate organic matter (POM) and the heavy material yielded the sand and $>63 \mu \mathrm{m}$ stable aggregates $(\mathrm{Sa}+A)$ fraction. The separated fractions were rinsed with deionized water and dried at $40^{\circ} \mathrm{C}$. A sub-sample of the silt and clay fraction was combined with $10 \mathrm{~mL}$ sodium hypochlorite and placed in a water bath at $95^{\circ} \mathrm{C}$ for $15 \mathrm{~min}$ (Anderson, 1963) to speed up the partial oxidation of the labile organic matter. The mixture was centrifuged for $8 \mathrm{~min}$ at $200 \times g$, decanted, and the oxidation, centrifugation, and decanting steps repeated twice. Finally, the residue was rinsed with deionized water and dried at $40^{\circ} \mathrm{C}$ to yield a resistant organic carbon (rSOC) fraction. Two aliquots of each soil sample were fractionated separately.

Total carbon (TC) of bulk soil and soil fractions were measured by dry combustion. Carbonate content of bulk soils was measured by the $\mathrm{HCl}$ gasometric method (Scheibler method) (Schlichting et al., 1995), while carbonates in the SOM frac- tions were destroyed by fumigation with hydrochloric acid (Harris et al., 2001). Bulk soils and fractions were then measured for TC by dry combustion with a Vario-EL III elemental analyzer (Elementar, Hanau, Germany).

\subsection{Incubation experiment}

Field moist samples from the Kraichgau and Swabian Alb sites' vegetated plots were sieved to $<4 \mathrm{~mm}$ and stored at $4^{\circ} \mathrm{C}$. One $\mathrm{kg}$ moist soil was transferred to $2.5 \mathrm{~L}$ glass jars and incubated in a dark, climate controlled room at $20^{\circ} \mathrm{C}$ for 490 days. The lids to the jars were left slightly open to enable gas exchange, but to prevent rapid drying. Additionally, a $100 \mathrm{~mL}$ beaker of deionized water was placed in the jars for better moisture retention. Periodically, deionized was added to the soils to keep the soil moisture content at $50 \%$ of field capacity.

Additionally, at the beginning of the experiment, two $20 \mathrm{~g}$ moist weight replicates were taken from each field sample, sieved to $2 \mathrm{~mm}$, adjusted to $50 \%$ of field capacity and placed in a Respicond IV automated respirometer (Nordgren Instruments, Bygdeå, Sweden) for the continuous measurement of $\mathrm{CO}_{2}$ evolution during 44 days at $20^{\circ} \mathrm{C}$ (the same temperature as the climate controlled room). At the end of the 44 day period, the incubation temperature was increased to $25^{\circ} \mathrm{C}$ (standard temperature for microbial biomass determination) and, after stabilization of respiration, a $1: 3(w: w)$ glucose and talc mixture was added to measure (substrate-induced) microbial biomass (Anderson and Domsch, 1978). A pre-test was done with varying amounts of glucose mixture, with the maximum respiration response being $\sim 0.16 \mathrm{~g}$ for Kraichgau and $\sim 0.32 \mathrm{~g}$ for Swabian Alb, respectively.

\subsection{FTIR-EGA method}

\subsubsection{Setup of FTIR-EGA thermal chamber}

For measuring thermally evolved gases, a high temperature heating system was utilized in conjunction with a Bruker Tensor 27 (Bruker Optik GmbH, Ettlingen, Germany) infrared spectrometer. The high temperature reaction chamber (HTC) (Harrick Scientific Products, Pleasantville, NY, USA) had an integrated sample holder which could hold approximately 50-70 mg of soil sample and was equipped with a cartridge type heating element and a K-type thermocouple. The HTC was interfaced with an automatic temperature controller (Harrick Scientific Products, Pleasantville, NY, USA) and with an integrated temperature/process controller (Watlow Winona, Minnesota, USA) for programmed heating rates and set-point temperatures. The HTC was closed by a gas tight dome with a high temperature O-ring. The dome had three windows, two made from potassium bromide to enable diffuse reflectance measurements (DRIFTS) of the soil, while the third window was made from quartz glass. The approximate internal volume of the heating chamber with 
a)
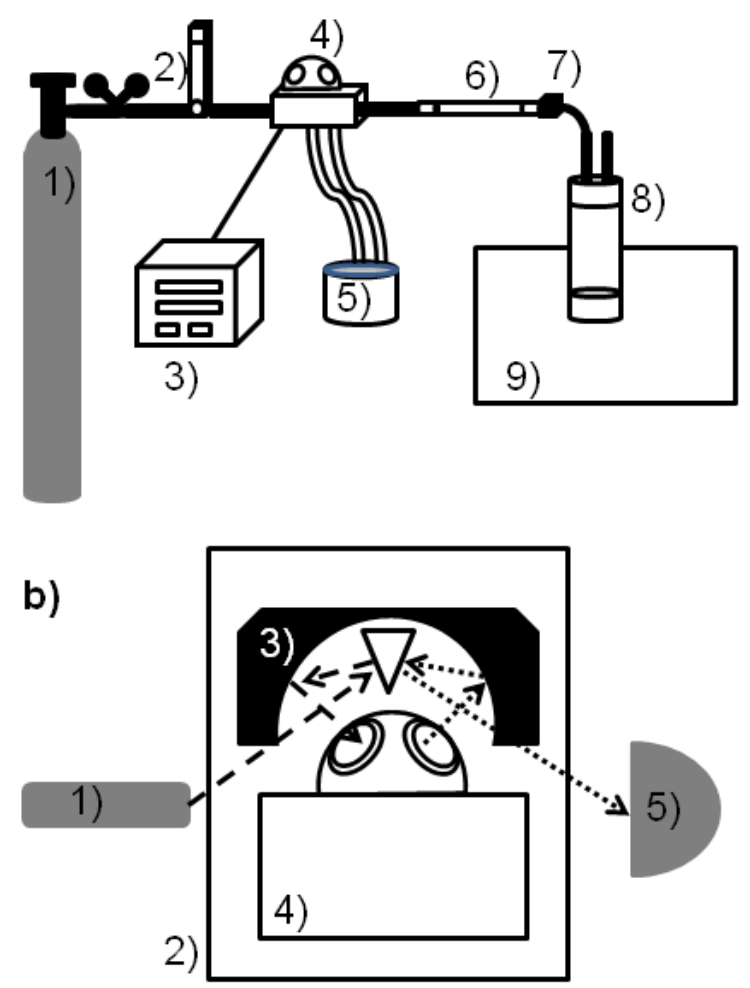

Fig. 1. Schematic of experimental setups. (a) FTIR-EGA system: (1) synthetic air purge/carrier gas, (2) pressure regulator and flow gauge, (3) automatic temperature controller, (4) high temperature reaction chamber with potassium bromide $(\mathrm{KBr})$ windows and integrated sample cup, (5) recirculating cooling water, (6) glass tube with magnesium perchlorate $\left(\mathrm{Mg}\left(\mathrm{ClO}_{4}\right)_{2}\right)$ water trap, (7) sintered metal particulate trap, (8) variable path length gas cell, (9) FTIR spectrometer). (b) In situ $T$ DRIFTS system: (1) infrared source, (2) diffuse reflectance chamber, (3) globular mirror, (4) high temperature reaction chamber with potassium bromide $(\mathrm{KBr})$ windows and integrated sample cup, (5) detector. Dashed lines indicate source infrared beam; dotted lines indicate diffusely reflected infrared beam.

installed dome was $20 \mathrm{~mL}$. In the gas measurement mode (FTIR-EGA), the heating chamber was linked via a stainless steel Swagelok system (Swagelok-Stuttgart GmbH, Reutlingen, Germany) to a variable long path gas cell (Bruker Optik $\mathrm{GmbH}$ ) which was placed in the accessory chamber of the Tensor 27 spectrometer (Fig. 1a). In the gas transfer line, immediately after the heating chamber, there was a water trap of magnesium perchlorate and a sintered metal filter $(2 \mu \mathrm{m})$ to prevent any particulate matter from reaching the gas cell and to act as a heat sink. The gas cell had a volume of $136 \mathrm{~mL}$ and a path length of $1 \mathrm{~m}$.

Taking into consideration the range of $\mathrm{C}$ contents of the samples to be analyzed $(0.13 \%$ being the lowest in the $\mathrm{NaOCl}$ oxidized silt + clay fraction to $48 \%$ in tannic acid) for this study, the state conditions of purge flow rate, sam- ple size, heating rate, infrared spectrometer scan rate, and mid-infrared wave number integration range were optimized (see Supplement Figs. S1-S4). This optimization was necessary to quantitatively determine the mid-infrared spectrometer signal response to total $\mathrm{C}$ amount, minimize secondary reactions, and to ensure similar heat transfer rates from the heating element to the sample, as the shape and distribution of the evolved gas were to be used as additional parameters to link to SOM properties.

After the pre-test the following procedure was adopted for the FTIR-EGA measurements. A scan was recorded every $4 \mathrm{~s}$, with a resolution of $8 \mathrm{~cm}^{-1}$. Synthetic air was used as the purge and carrier gas of the system with a flow rate of $15 \mathrm{~L} \mathrm{~h}^{-1}$. The chamber was purged for $5 \mathrm{~min}$ after introducing the sample. Additionally, a baseline was taken before the beginning of each analysis in order to zero the signal in the gas cell. An optimized heating rate of $68^{\circ} \mathrm{C} \mathrm{min}^{-1}$ (see section below) and set-point temperature of $700^{\circ} \mathrm{C}$ were used. The set-point temperature was reached after $10 \mathrm{~min}$ and held for another $20 \mathrm{~min}$, which resulted in a total of 400 individual FTIR scans. After pretesting, in which it was found that $\mathrm{CO}_{2}$ evolution ended after a shorter time duration, the final number of scans taken was reduced to 300 for a total analysis time of $20 \mathrm{~min}$.

In the present experiment, lower heating rates were also tested $\left(10\right.$ and $\left.28^{\circ} \mathrm{C} \mathrm{min}^{-1}\right)$, but were found to result in an increase in the formation of secondary reaction products during heating, as shown by in situ ${ }_{T}$ DRIFTS (see Fig. S3). Heating rates $>68^{\circ} \mathrm{C} \mathrm{min}^{-1}$ resulted, however, in non-linear increases in temperature and an overshoot of the final set-point temperature. After the heating rate was set, the purge gas flow rate was adjusted in order that the maximum absorbance of the $\mathrm{CO}_{2}$ peak ( 2400 to $2200 \mathrm{~cm}^{-1}$ ) evolution was $<2.5 \mathrm{ab}$ sorbance units (A.U.). If the absorbance is $>2.5$ A.U., then there may not be a linear relationship between absorbance and the content of the compound of interest (Conzen, 2003). A relatively high purge rate of $15 \mathrm{~L} \mathrm{~h}^{-1}$ was needed in order to minimize retention time in the gas cell due to the large volume $(136 \mathrm{~mL})$. The scanning or wavenumber resolution of $8 \mathrm{~cm}^{-1}$ was found adequate, as the main gas of interest, $\mathrm{CO}_{2}$, has a relatively broad spectral absorbance range (100 wavenumbers) and does not require a very high resolution. The time in between each scan was first set at $40 \mathrm{~s}$ as this was the calculated time to purge the entire system, but was found to be too coarse a measurement interval, especially for rapid increases in $\mathrm{CO}_{2}$ evolution. A scan every $4 \mathrm{~s}$ gave a better time resolution of the rate of change with respect to time of $\mathrm{CO}_{2}$ evolution. It was found that if any of these state variables were changed (i.e., purge rate, scan time, resolution, or heating rate), then a new calibration curve would need to be constructed to quantify $\mathrm{CO}_{2}$ evolution. 


\subsubsection{Deriving FTIR-EGA thermal characteristics}

The individual scans from a single FTIR-EGA analysis were then assembled into a single file or thermogram for further processing using the spectral processing software OPUS v 6.5 (Bruker Optik GmbH). The spectra were baseline corrected using the concave rubberband method with 64 baseline points and 10 iterations. Integration was performed on the baseline corrected spectra between 2400 to $2200 \mathrm{~cm}^{-1}$, following Eq. (1):

Area peak $=\int_{2200 \mathrm{~cm}^{-1}}^{2400 \mathrm{~cm}^{-1}} A(v)$

where $A(v)$ is the absorbance value of the investigated wavenumbers. The cumulative peak area was calculated by Eq. (2):

Area $_{\text {cum }}=\sum_{j=1}^{300} j\left(\right.$ Area $\left._{\text {peak }}\right)$

where $j$ is the scan number, which was taken every $4 \mathrm{~s}$ for a total of 300 scans, and $j\left(\right.$ Area $\left._{\text {peak }}\right)$ is the Area peak at scan $j$. The presence of a linear response of cumulative peak area found by Eq. (2) to the theoretical $\mathrm{CO}_{2}$ yield of the thermal decomposition of a sodium bicarbonate standard was checked to establish a quantitative relationship.

Each $\mathrm{CO}_{2}$ evolution thermogram was exported from OPUS and further processed in Excel (Microsoft) to normalize Area $a_{\text {peak }}$ to analyzed sample weight:

Area $_{\mathrm{wt}}=\frac{\text { Area }_{\text {peak }}}{\text { sample weight }(\mathrm{mg})}$.

Furthermore, different characteristics of the nature of $\mathrm{CO}_{2}$ evolution were calculated including normalizing Area $a_{\text {peak }}$ to C content:

Area $_{\mathrm{C}}=\frac{\text { Area }_{\text {peak }}}{\text { sample weight } \times \mathrm{C}_{\text {org }} \text { content }}$

where $\mathrm{C}_{\text {org }}$ content is the total organic $\mathrm{C}$ content of the sample as measured by elemental analyzer minus any carbonates.

The temperature of maximum $\mathrm{CO}_{2}$ evolution was identified with the following equation:

$\mathrm{CO}_{2_{\max }}=\max _{25}^{700} f\left(\right.$ Area $\left._{\text {peak }}\right)$,

during the heating from 25 to $700^{\circ} \mathrm{C}$.

Due to the large range in $\mathrm{C}$ contents of samples analyzed ( 0.1 to $48 \%$ OC), the sample weight was adjusted to fit into a range from 0.1 to $2.5 \mathrm{mg}$ OC content in order to stay within the linear range of the calibration curve (Fig. 3). In the case of POM, which had between $26-32 \% \mathrm{C}$ by weight, the above $\mathrm{C}$ content would only result in a maximum sample weight

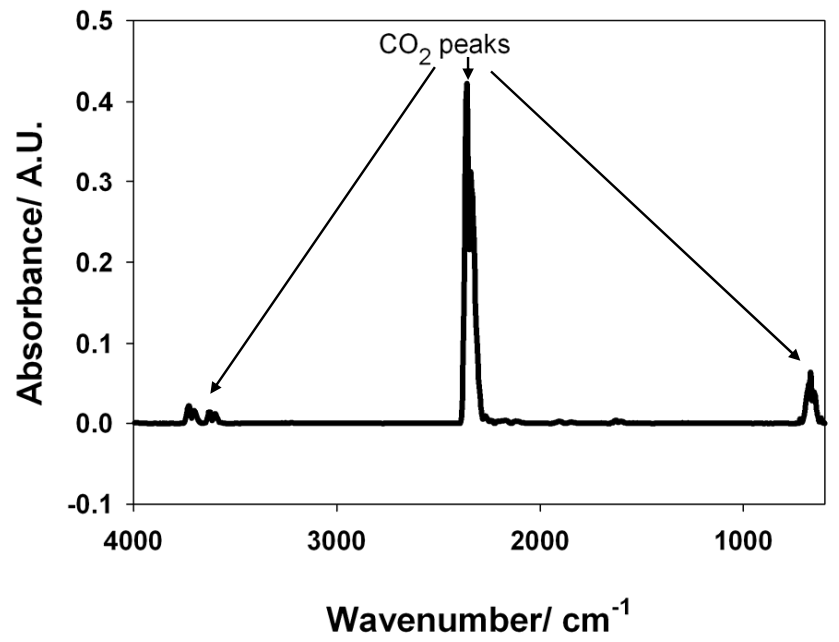

Fig. 2. Single scan of online evolved gas as measured by the FTIREGA system, with corresponding $\mathrm{CO}_{2}$ peaks.

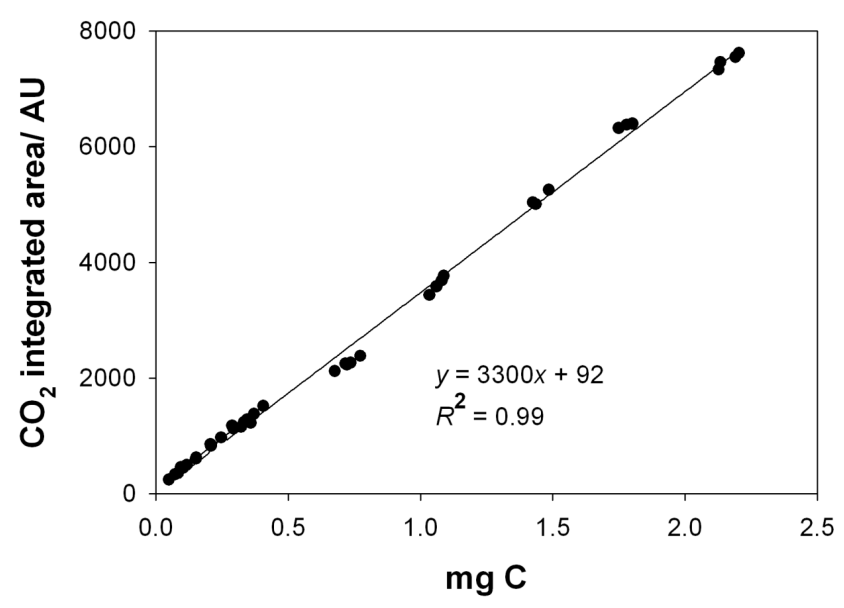

Fig. 3. $\mathrm{CO}_{2}$ calibration curve of the FTIR-EGA with $\mathrm{NaHCO}_{3}$.

of $6 \mathrm{mg}$ as compared to 30 to $50 \mathrm{mg}$ of the other fractions and bulk soil. Thus, due to the small sample weight and the small volume occupied within the heating chamber, a $1: 50$ dilution was made with ball-milled quartz sand, which had previously been heated to $600^{\circ} \mathrm{C}$ overnight to remove any $\mathrm{C}$ impurities. This dilution ratio was used to gain roughly the same volume of material as was analyzed with the bulk soil and lower $\mathrm{C}$ content fractions and to result in $\mathrm{C}$ amounts between the 0.1 to $2.5 \mathrm{mg}$ range.

\subsection{In situ $T$ DRIFTS method}

To follow the molecular vibrational changes of the soil sample during heating, a Praying Mantis diffuse reflectance (DRIFTS) chamber (Harrick Scientific) was fitted in the Tensor 27 (Bruker Optik GmbH) and the HTC (Harrick Scientific) placed inside the DRIFTS chamber to record absorbance measurements from 4000 to $400 \mathrm{~cm}^{-1}$ of the bulk 
soil or SOM fraction surfaces during heating, thus referred to in this paper as in $\operatorname{situ}_{T}$ DRIFTS (Fig. 1b). The heating conditions and purge rate remained the same as in the FTIR-EGA mode. A scan was taken every $4 \mathrm{~s}$ at a resolution of $4 \mathrm{~cm}^{-1}$. Potassium bromide $(\mathrm{KBr})$ was used to take a background scan before measuring the sample. Additionally the POM fraction was diluted $1: 50$ with $\mathrm{KBr}$ for analysis. Identification of important wavenumbers corresponding to OM functional groups was done based on the assignments by Demyan et al. (2012) and also by inspecting which wavenumbers were changing in intensity during the heating experiment. As previously mentioned, not only is $\mathrm{OM}$ thermal degradation ongoing during this temperature interval $\left(200-700^{\circ} \mathrm{C}\right.$ ) but also water loss and mineral changes (silica structure) occur. The known $\mathrm{OH}$ stretching area at 3400 to $3000 \mathrm{~cm}^{-1}$ was used to monitor changes in water loss and was compared to behavior of other bands to determine if there was also an influence of water loss on the decrease of a peak instead of OM combustion. Collected spectra were baseline corrected as described above and smoothed using a running average with a 15 point window.

\subsection{Data combination of FTIR-EGA and in $\operatorname{situ}_{T}$ DRIFTS for curve fitting}

The Area $_{w t}$ outputs from a single FTIR-EGA analysis (300 readings) (Eq. 3) of bulk soil were then subjected to a curve fitting procedure. First, changes in molecular vibration intensities related to specific OM compounds were followed during the heating process between 200 and $700^{\circ} \mathrm{C}$ using in $\mathrm{situ}_{T}$ DRIFTS. A decrease in the identified molecular vibrational peaks during this period were assumed to coincide with the combustion of OM. Points of maximum decrease were identified by using $100 \%$ of the value at $200^{\circ} \mathrm{C}$ (start of thermal degradation of $\mathrm{OM}$ ) and calculating the rate of change between each measurement point. These points of largest decrease were then taken as center points for the fitted components of the peak fitting procedure of the FTIREGA evolved $\mathrm{CO}_{2}$ of the bulk soil. A series of constraints were made for the curve deconvolution routine based on the results of the in $\operatorname{situ}_{T}$ DRIFTS results. Temperatures of maximum decrease in intensity of a vibrational organic functional group above $200^{\circ} \mathrm{C}$ were taken to be the peak of an individual "component" of the FTIR-EGA $\mathrm{CO}_{2}$ profile. The most rapid decreases of the peak intensities were found at the following temperatures: 1 st peak at $320^{\circ} \mathrm{C}$ of the CO vibrations $\left(2200-2000 \mathrm{~cm}^{-1}\right)$, 2nd peak at $380^{\circ} \mathrm{C}$ of the C-H vibrations (3000-2800 $\left.\mathrm{cm}^{-1}\right)$, 3rd peak $\mathrm{COO}^{-} / \mathrm{C}=\mathrm{C}$ $\left(1620 \mathrm{~cm}^{-1}\right)$, and 4 th peak at $1525 \mathrm{~cm}^{-1}(\mathrm{C}=\mathrm{C})$. An iterative least squares approach was used for the curve fitting of the $\mathrm{CO}_{2}$ evolved gas profiles using the software PeakFit version 4.12 (Systat Software, San Jose, California, USA). Additionally, the following rules were followed during FTIREGA peak fitting: peaks were placed first where there was a visible peak or a change in the rate of increase or decrease of
$\mathrm{CO}_{2}$ evolution as determined by 2 nd derivative, peaks were then added at the local maximum of the residuals to improve the $R^{2}$ and decrease the standard error (SE). The temperatures of these peak positions were again verified with the results from the in situ ${ }_{T}$ DRIFTS given above to justify the presence of a specific component at a certain temperature. The residuals of the final fit were also inspected for normality and heteroscedasticity. A fitting procedure was considered completed when $R^{2}>0.999$, $\mathrm{SE}<0.005$ and there was a homoscedasticity of residuals. The peak fitting was repeated three times on a single analytical replicate to ensure stability or robustness of the fit and to determine if the fit was the most likely combination of solutions based on the data.

Analysis of variance (significance at $P<0.05$ ) was used to compare $\mathrm{CO}_{2_{\max }}$ among the treatments at the Bad Lauchstädt site. A mixed modeling approached was used to compare the $\mathrm{CO}_{2 \max }$ of the bulk soils and fractions in Kraichgau and Swabian Alb areas. The factors were site and fraction, with plot location as the random error.

\section{Results}

\subsection{Soil characteristics}

Results of total $\mathrm{C}$ elemental analysis revealed that the soils of Swabian Alb had nearly double the TOC content (18.33 $\mathrm{mg} \mathrm{Cg}^{-1}$ soil) compared to the Kraichgau site (9.17 $\mathrm{mg} \mathrm{Cg}^{-1}$ soil) (Table 2). The TOC contents ranged from a low 14.8 in the $\mathrm{CON}$ to $21.2 \mathrm{mg} \mathrm{Cg}^{-1}$ soil in the FYM + NPK treatment. Carbon contents of the fractions were generally twice the amount in the Swabian Alb as compared to the Kraichgau with the exception of extractible SOM, which was only $0.04 \mathrm{mg} \mathrm{Cg}^{-1}$ soil in the Kraichgau compared to $0.36 \mathrm{mg} \mathrm{Cg}^{-1}$ soil in the Swabian Alb. Additionally, microbial biomass $\mathrm{C}$ as measured by the SIR method of incubated soils was more than twice as much in the Swabian Alb site $\left(0.59 \mathrm{mg} \mathrm{C} \mathrm{g}^{-1}\right.$ soil $)$ as compared to the Kraichgau site $\left(0.24 \mathrm{mg} \mathrm{C} \mathrm{g}^{-1}\right.$ soil).

\subsection{FTIR-EGA derived properties of organic substances}

In order to quantify evolved $\mathrm{CO}_{2}$ from the thermal reactions, sodium bicarbonate was used as a standard due to its known stoichiometric thermal decomposition (Janković, 2009). An example of a single mid-infrared gas cell scan of evolved gas from $\mathrm{NaHCO}_{3}$ decomposition can be found in Fig. 2, showing the three main vibrational modes of $\mathrm{CO}_{2}$ (in order of decreasing intensity) at 2400-2200, 715-615, and 3760$3657 \mathrm{~cm}^{-1}$. Absorbance values of $>2.5$ of the main $\mathrm{CO}_{2}$ peak at $2400-2200 \mathrm{~cm}^{-1}$ resulted in a non-linear response of $\mathrm{Area}_{\text {cum }}$ and calculated $\mathrm{C}$ evolved from the $\mathrm{NaHCO}_{3}$ (see Fig. S4). Thus, for the heating rate of $68^{\circ} \mathrm{C} \mathrm{min}^{-1}$ and reaction chamber purge rate of $15 \mathrm{Lh}^{-1}$, a $\mathrm{C}$ weight between $0.1-2.5 \mathrm{mg}$ could be analyzed and resulted in a linear 
Table 2. Mean values ( \pm standard errors) of organic carbon (OC) of bulk soil and fractions from the sites of Bad Lauchstädt, Kraichgau, and Swabian Alb based on oven dried $\left(105^{\circ} \mathrm{C}\right)$ basis. All values are $\mathrm{mg} \mathrm{Cg}^{-1}$ bulk soil.

\begin{tabular}{lcccccc}
\hline Soil parameter & \multicolumn{5}{c}{ Site } \\
& Kraichgau & Swabian Alb & \multicolumn{3}{c}{ Bad Lauchstädt } \\
\cline { 2 - 7 } & & & FYM + NPK & FYM & NPK & CON \\
Bulk soil & $9.17(0.24)$ & $18.33(1.16)$ & $22.1(1.1)$ & $20.4(0.8)$ & $16.5(0.3)$ & $14.8(0.3)$ \\
Extractible & & & & & & \\
SOM & $0.04(0.00)$ & $0.36(0.02)$ & nd $^{\mathrm{b}}$ & nd & nd & nd \\
POM & $0.84(0.07)$ & $1.34(0.14)$ & nd & nd & nd & nd \\
Sa $+A$ & $0.42(0.02)$ & $0.63(0.09)$ & nd & nd & nd & nd \\
Si $+\mathrm{C}$ & $7.92(0.14)$ & $13.31(0.59)$ & nd & nd & nd & nd \\
rSOC & $1.38(0.05)$ & $2.94(0.24)$ & nd & nd & nd & nd \\
$\mathrm{C}_{\text {mic }}$ & $0.24(0.04)$ & $0.59(0.07)$ & nd & nd & nd & nd \\
C lost $^{\mathrm{c}}$ & $0.9(0.01)$ & $1.9(0.07)$ & nd & nd & nd & nd \\
\hline
\end{tabular}

a Bulk soil $<2 \mathrm{~mm}$, Extractible SOM-dissolved SOM captured during wet sieving of silt and clay from sand and stable aggregates, POM-sand fraction $<1.8 \mathrm{~g} \mathrm{~cm}^{-3}, \mathrm{Sa}+A$ sand fraction $>1.8 \mathrm{~g} \mathrm{~cm}^{-3}, \mathrm{Si}+\mathrm{C}<63 \mu \mathrm{m}, \mathrm{rSOC}<63 \mu \mathrm{m}$ treated with hot sodium

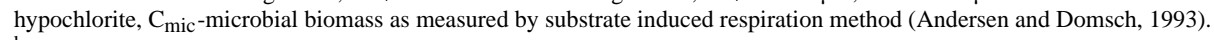

$\mathrm{b}$ Not determined.

c Carbon lost over 490 day incubation at $20^{\circ} \mathrm{C}$ and $50 \%$ water holding capacity.

response $\left(R^{2}=0.99\right)$ (Fig. 3). The three pure substances (i.e., glucose, xylan, tannic acid) had very different FTIR-EGA $\mathrm{CO}_{2}$ thermograms, such as number of peaks, peak position and general shape of the curve of $\mathrm{CO}_{2}$ evolution (Fig. 4). In the undiluted samples (Fig. 4a), xylan was found to have the first $\mathrm{CO}_{2}$ evolution peak at $320^{\circ} \mathrm{C}$, one at $500^{\circ} \mathrm{C}$, and the highest $\mathrm{CO}_{2}$ temperature peak at $680^{\circ} \mathrm{C}$. Undiluted glucose had a prominent peak at $442{ }^{\circ} \mathrm{C}$ and a shoulder at $537^{\circ} \mathrm{C}$. The first two $\mathrm{CO}_{2}$ peaks of undiluted tannic acid were present at 380 and $450{ }^{\circ} \mathrm{C}$, and a final peak at $660^{\circ} \mathrm{C}$. To test if there was any effect on sample volume to FTIR-EGA derived thermal characteristics, a dilution of $1: 100(w / w)$ with preheated quartz sand was done. This dilution resulted in relatively the same volume of heating chamber occupied compared with the bulk soils for the same quantity of OC. The dilution resulted in shifts of the peak temperatures and also the peak heights relative to $\mathrm{C}$ content. Xylan still had the earliest $\mathrm{CO}_{2}$ peak, but that was shifted to a higher temperature at $346^{\circ} \mathrm{C}$ and a second peak at $518^{\circ} \mathrm{C}$. Glucose had only one $\mathrm{CO}_{2}$ peak at $380^{\circ} \mathrm{C}$. Tannic acid had two poorly resolved peaks, one at $410^{\circ} \mathrm{C}$ and a final peak around $577^{\circ} \mathrm{C}$. As a percentage of total evolved $\mathrm{C}, 80 \%$ was recovered upon reaching $700^{\circ} \mathrm{C}(10 \mathrm{~min})$ from undiluted samples, while in the diluted samples, $90 \%$ was recovered.

\subsection{FTIR-EGA derived properties of soils and fractions}

The $\mathrm{CO}_{2 \max }$ varied both by long-term fertilizer application in the case of the Bad Lauchstädt soils (Table 3) and also when comparing by site (Bad Lauchstädt, Kraichgau, Swabian Alb) (Fig. 5). In the Bad Lauchstädt soils, the $\mathrm{CO}_{2_{\max }}$ increased from $419^{\circ} \mathrm{C}$ in the FYM $+\mathrm{NPK}$ treatment to $428^{\circ} \mathrm{C}$ in FYM and $473^{\circ} \mathrm{C}$ in the NPK and control soils. Compared to the TOC contents (Table 2 ), which were only signif-

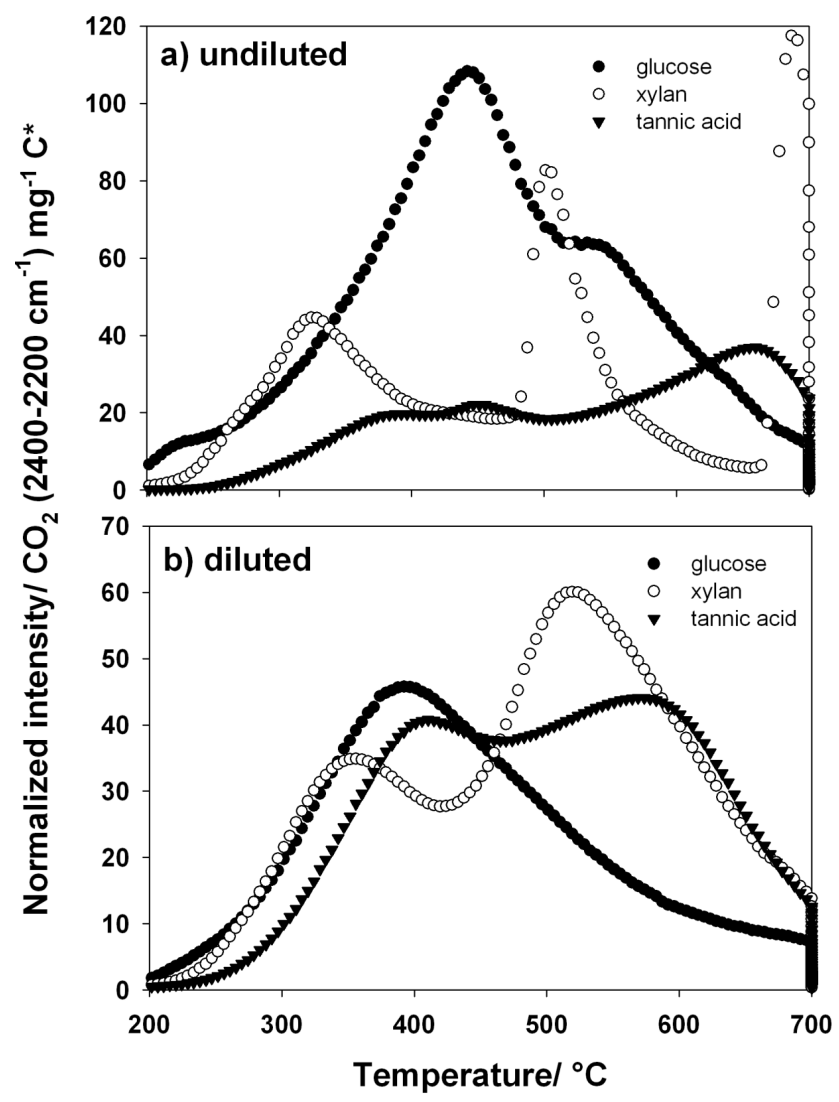

Fig. 4. FTIR-EGA $\mathrm{CO}_{2}$ thermograms of three selected substances. (a) neat samples, (b) diluted 1:100 with preheated, ball-milled quartz sand. * Normalized intensity is the integrated area of the $\mathrm{CO}_{2}$ peak from 2400 to $2200 \mathrm{~cm}^{-1}$ normalized to $\mathrm{C}$ content of the sample. 


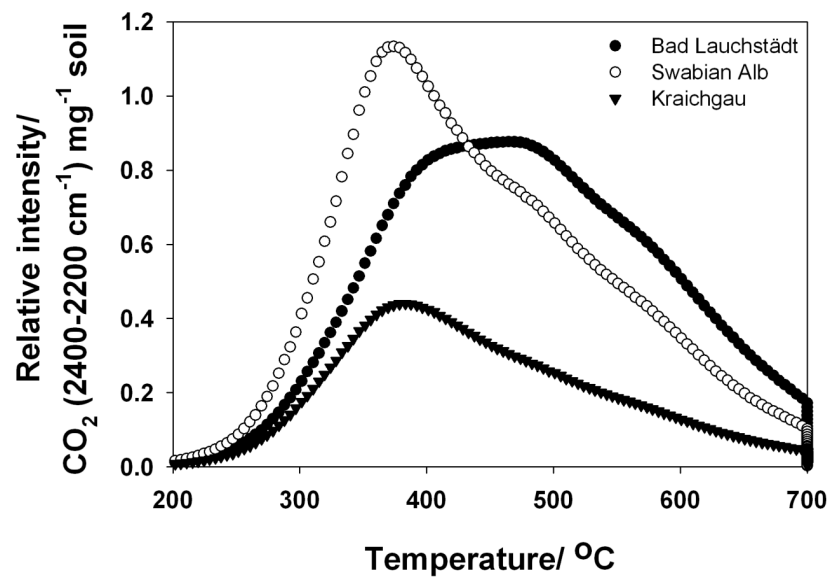

Fig. 5. FTIR-EGA average $\mathrm{CO}_{2}$ thermograms of soils from three different agroecological sites (Bad Lauchstädt, Kraichgau, Swabian $\mathrm{Alb}) .{ }^{*}$ Normalized intensity is the integrated area of the $\mathrm{CO}_{2}$ peak from 2400 to $2200 \mathrm{~cm}^{-1}$ normalized to weight of the sample.

icantly affected by FYM application, the FTIR-EGA method also indicated a difference between the FYM + NPK and FYM treatments. When comparing soils from the three sites (Fig. 5), the peak $\mathrm{CO}_{2}$ evolution not only had different maximum heights for the three soils, but also different temperatures. The average for the Swabian Alb site soils had the lowest $\mathrm{CO}_{2_{\max }}$ at $384^{\circ} \mathrm{C}$, while that of the Kraichgau soils was at a significantly higher $(P<0.05)$ temperature $\left(392^{\circ} \mathrm{C}\right)$. The $\mathrm{CO}_{2_{\max }}$ average of all Bad Lauchstädt samples was much later at $447^{\circ} \mathrm{C}(P<0.05)$, even factoring in the effect of long-term manure treatment. The $\mathrm{CO}_{2}$ thermograms further revealed that while the Kraichgau and Swabian Alb soils had a similar $\mathrm{CO}_{2}$ evolution pattern with a rapid increase in $\mathrm{CO}_{2}$ evolution between 275 to $380^{\circ} \mathrm{C}$ (Fig. 5), the Bad Lauchstädt soils had a much broader peak covering a range of approximately $80^{\circ} \mathrm{C}$ (Fig. 5). Compared with the results from the elemental analyzer, total $\mathrm{C}$ contents as measured by FTIREGA were underestimated on average by $7 \%$.

Soils measured after incubation for 490 days showed a decrease in thermally evolved $\mathrm{CO}_{2}$ (Fig. 7) and a shift in the $\mathrm{CO}_{2 \max }$. The difference $\mathrm{CO}_{2}$ thermograms (Fig. 7c) taken by subtracting the two thermograms show from which temperature regions $\mathrm{C}$ has been released during the longterm incubation. The maximum difference between pre- and post-incubation evolved $\mathrm{CO}_{2}$ was at 360 and $378^{\circ} \mathrm{C}$ for the Kraichgau and Swabian Alb, respectively, with $\mathrm{CO}_{2 \text { max }}$ shifted to a slightly higher temperature (increase of $4{ }^{\circ} \mathrm{C}$ ).

The temperature of the individual $\mathrm{CO}_{2}$ evolution peaks of SOM fractions separated from the bulk soil of the Kraichgau and Swabian Alb sites were generally found to be the same among the sites, with the exception of the second peak of rSOC fraction, which was much higher at the Kraichgau site $\left(482^{\circ} \mathrm{C}\right)$ compared to the Swabian Alb site $\left(392^{\circ} \mathrm{C}\right)(\mathrm{Ta}-$
Table 3. FTIR-EGA measured peak temperature of $\mathrm{CO}_{2}$ evolution during heating from 25 to $700{ }^{\circ} \mathrm{C}$ of soils from the Static Fertilization Experiment, Bad Lauchstädt (average years 1956, 1992, 2004). Values in parentheses are standard errors. Different letters within each column indicate a significant difference $(P<0.05)$ among the four treatments.

\begin{tabular}{lc}
\hline Treatment & Peak temperature ${ }^{\circ} \mathrm{C}$ \\
\hline${\text { FYM }+ \text { NPK }^{*}}_{\text {FYM }^{*}}$ & $419(3) \mathrm{a}$ \\
NPK $^{*}$ & $428(2) \mathrm{b}$ \\
Control $^{*}$ & $473(2) \mathrm{c}$ \\
\hline
\end{tabular}

* FYM + NPK (farmyard manure and mineral fertilizer), FYM (farmyard manure), NPK (mineral fertilizer), Control (no fertilizer inputs).

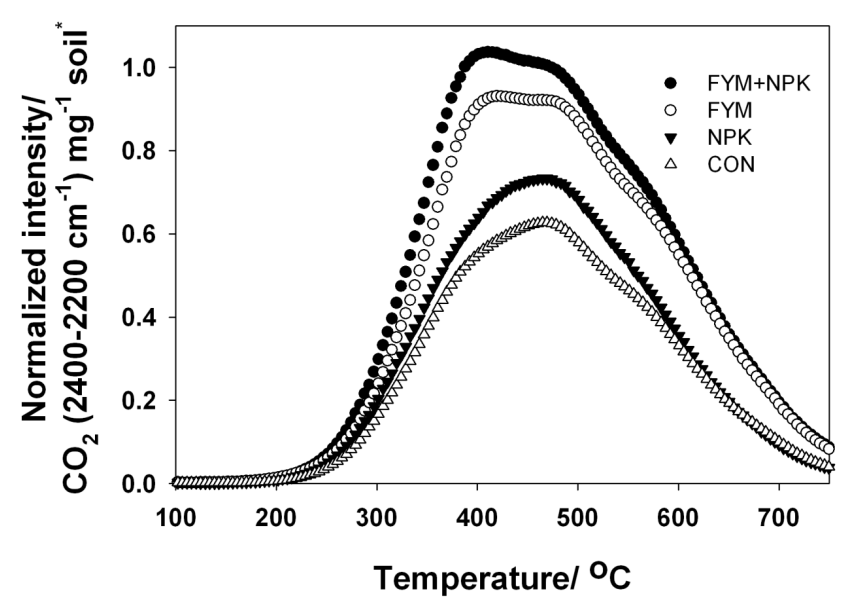

Fig. 6. FTIR-EGA $\mathrm{CO}_{2}$ thermograms of bulk soil from the Static Fertilization Experiment, Bad Lauchstädt, heating from 25 to $700^{\circ} \mathrm{C}$ at $68^{\circ} \mathrm{C} \mathrm{min}{ }^{-1}$ under synthetic air purge. Treatments: $\mathrm{FYM}+\mathrm{NPK}$ (farmyard manure and mineral fertilizer), FYM (farmyard manure), NPK (mineral fertilizer), CON (no fertilizer inputs). * Normalized intensity is the integrated area of the $\mathrm{CO}_{2}$ peak from 2400 to $2200 \mathrm{~cm}^{-1}$ normalized to weight of the sample.

ble 4, Fig. 8). The largest differences in relation to the bulk soil were the rSOC fractions, which had two well defined peaks and the POM, which had a first poorly defined peak or "shoulder" around $380^{\circ} \mathrm{C}$, the same temperature as the bulk soil, but then a main peak much later compared to the bulk soil at $477^{\circ} \mathrm{C}$ (Fig. 8). C contents of the fractions as estimated by FTIR-EGA compared with the elemental analyzer were $7 \%$ overestimated in the case of $\mathrm{Sa}+A$ and $\mathrm{rSOC}$, $8 \%$ underestimated in $\mathrm{Si}+\mathrm{C}$ and $20 \%$ underestimated in the case of POM.

\subsection{In $\operatorname{situ}_{T}$ DRIFTS}

In situ $_{T}$ thermal DRIFTS measurements showed changing vibrational intensities which depended on the heating chamber temperature and the functional groups being studied. 
Table 4. Mean values ( \pm standard error) for soil (Kraichgau and Swabian Alb) at the temperatures $\left({ }^{\circ} \mathrm{C}\right)$ of peaks or "shoulders" of thermally evolved $\mathrm{CO}_{2}$ of bulk soil and SOM fractions as measured by FTIR-EGA. Lowercase letters indicate significant differences $(P<0.05)$ between peak temperatures in a row (among the sites), uppercase letters indicate significant differences $(P<0.05)$ within a site among fractions.

\begin{tabular}{|c|c|c|c|c|c|c|}
\hline \multirow[b]{3}{*}{ Fraction } & \multicolumn{6}{|c|}{ Site } \\
\hline & \multicolumn{3}{|c|}{ Kraichgau } & \multicolumn{3}{|c|}{ Swabian Alb } \\
\hline & $200-350^{\circ} \mathrm{C}$ & $350-450{ }^{\circ} \mathrm{C}$ & $450-550^{\circ} \mathrm{C}$ & $200-350^{\circ} \mathrm{C}$ & $350-450^{\circ} \mathrm{C}$ & $450-550^{\circ} \mathrm{C}$ \\
\hline Bulk soil $^{\mathrm{a}, \mathrm{b}}$ & 392(2)Aa & & & $384(2) \mathrm{Ab}$ & & \\
\hline $\mathrm{POM}^{\mathrm{a}, *}$ & & & 477(5)B & & & 476(6)B \\
\hline $\mathrm{Sa}+A^{\mathrm{a}}$ & & $362(1) A$ & & & $369(7) \mathrm{A}$ & \\
\hline $\mathrm{Si}+\mathrm{C}$ & & 400(1)A & & & 399(4)A & \\
\hline $\mathrm{rSOC}^{\mathrm{a}}$ & $265(1) \mathrm{C}$ & & 482(17)Ba & $265(5) \mathrm{C}$ & & $392(15) \mathrm{Ab}$ \\
\hline
\end{tabular}

Table 5. Temperature and relative contribution to total evolved $\mathrm{CO}_{2}$ of fitted peaks/components ( \pm standard errors) from an iterative least squares approach of thermally evolved $\mathrm{CO}_{2}$ from 25 to $700{ }^{\circ} \mathrm{C}\left(68^{\circ} \mathrm{C} \mathrm{min}{ }^{-1}\right.$ heating rate $)$ as measured by FTIR-EGA. Peak temperatures of the components were derived from relative changes of vibrational intensity of organic functional groups by in situ ${ }_{T}$ DRIFTS.

\begin{tabular}{lcccccccc}
\hline Site & \multicolumn{2}{c}{ Component 1} & \multicolumn{2}{c}{ Component 2 } & \multicolumn{2}{c}{ Component 3 } & \multicolumn{2}{c}{ Component 4 } \\
\hline & Temp $/{ }^{\circ} \mathrm{C}$ & $\%^{\mathrm{a}}$ & $\mathrm{Temp} /{ }^{\circ} \mathrm{C}$ & $\%$ & $\mathrm{Temp} /{ }^{\circ} \mathrm{C}$ & $\%$ & $\mathrm{Temp} /{ }^{\circ} \mathrm{C}$ & $\%$ \\
\hline BL FYM + NPK & $298(2)$ & $4.2(0.1)$ & $361(2)$ & $25.0(1.8)$ & $442(2)$ & $27.3(1.1)$ & $540(3)$ & $43.4(0.7)$ \\
$\mathrm{BL} \mathrm{FYM}$ & $301(3)$ & $4.4(0.3)$ & $367(3)$ & $23.0(0.7)$ & $446(3)$ & $26.9(0.8)$ & $547(6)$ & $45.1(1.1)$ \\
$\mathrm{BL} \mathrm{NPK}$ & $293(1)$ & $3.3(0.0)$ & $360(0)$ & $18.8(0.4)$ & $439(1)$ & $28.1(0.7)$ & $528(5)$ & $49.1(1.0)$ \\
BL CON & $292(2)$ & $3.7(0.2)$ & $357(1)$ & $18.6(1.3)$ & $435(1)$ & $28.6(2.5)$ & $527(5)$ & $49.2(1.6)$ \\
Kraichgau & $290(2)$ & $3.4(0.2)$ & $353(1)$ & $46.1(0.6)$ & $445(1)$ & $27.3(0.4)$ & $549(2)$ & $23.3(0.6)$ \\
Swabian Alb & $289(2)$ & $4.7(0.3)$ & $344(1)$ & $35.3(1.0)$ & $432(2)$ & $33.9(0.7)$ & $541(2)$ & $26.1(0.9)$ \\
\hline
\end{tabular}

a Percent contribution of component to total evolved $\mathrm{CO}_{2}$.

${ }^{\mathrm{b}}$ BL - Bad Lauchstädt experiment; FYM + NPK - farmyard manure and NPK fertilizer, FYM - farmyard manure, NPK - NPK fertilizer, CON - control.

Certain organic functional group associated vibrations (i.e., aliphatic, carboxylate, aromatic) differed in their temperature sensitivity shown by specific temperature ranges of changing vibrational intensity (Figs. 9-11). In the bulk soil samples, consistent changes were found for all three sites with regard to the $\mathrm{C}-\mathrm{H}$ and $-\mathrm{COO}^{-} / \mathrm{C}=\mathrm{C}$ vibrations. The $\mathrm{C}-\mathrm{H}$ vibrations consistently decreased starting 220 to $250^{\circ} \mathrm{C}$ and accelerating rapidly around $350^{\circ} \mathrm{C}$, while the $-\mathrm{COO}^{-} / \mathrm{C}=\mathrm{C}$ vibrations began to decrease around $380^{\circ} \mathrm{C}$ with a maximum decline around $440^{\circ} \mathrm{C}$. Between 300 to $370^{\circ} \mathrm{C}$, there was a drastic decrease in $\mathrm{C}-\mathrm{H}$ vibrations while at the same temperature range there was a slight increase in $\mathrm{C}=\mathrm{C} /-\mathrm{COO}$ vibrations and a stronger increase in $\mathrm{C}=\mathrm{C}$ vibrations. At approximately $400^{\circ} \mathrm{C}$, the $\mathrm{C}=\mathrm{C} /-\mathrm{COO}$ vibrations decreased and after $430{ }^{\circ} \mathrm{C}$ the $\mathrm{C}=\mathrm{C}$ vibrations decreased. Vibration intensities of wavenumbers below $1000 \mathrm{~cm}^{-1}$ were rather difficult to interpret due to the lack of clear trends, high variation from one scan to the next, and absorbance values of $>2.5$ A.U., especially at temperatures $>500^{\circ} \mathrm{C}$.
Differences among the fractions via in situ ${ }_{T}$ DRIFTS is illustrated in Fig. 10 for the $\mathrm{C}-\mathrm{H}$ and $-\mathrm{COO}^{-} / \mathrm{C}=\mathrm{C}$ vibrational groups as an average of the Kraichgau and Swabian Alb samples. The behavior of the $2930 \mathrm{~cm}^{-1}$ peak is consistent among the fractions with the exception of the rSOC fraction from the Kraichgau site. After an initial slight decrease between 200 to $250^{\circ} \mathrm{C}$, the decrease in intensity of the $2930 \mathrm{~cm}^{-1}$ peak accelerated after $280^{\circ} \mathrm{C}$ with the decrease in intensity ending around $450^{\circ} \mathrm{C}$. The POM fractions showed an increased in intensity after $550^{\circ} \mathrm{C}$, until $700^{\circ} \mathrm{C}$. The $1620 \mathrm{~cm}^{-1}$ peak was found to be relatively stable from 200 and $220^{\circ} \mathrm{C}$ and then increase in intensity from $280^{\circ} \mathrm{C}$ to approximately $360^{\circ} \mathrm{C}$ with some variation between fractions. The onset of decrease was around $380^{\circ} \mathrm{C}$, the same as for the bulk soils. 


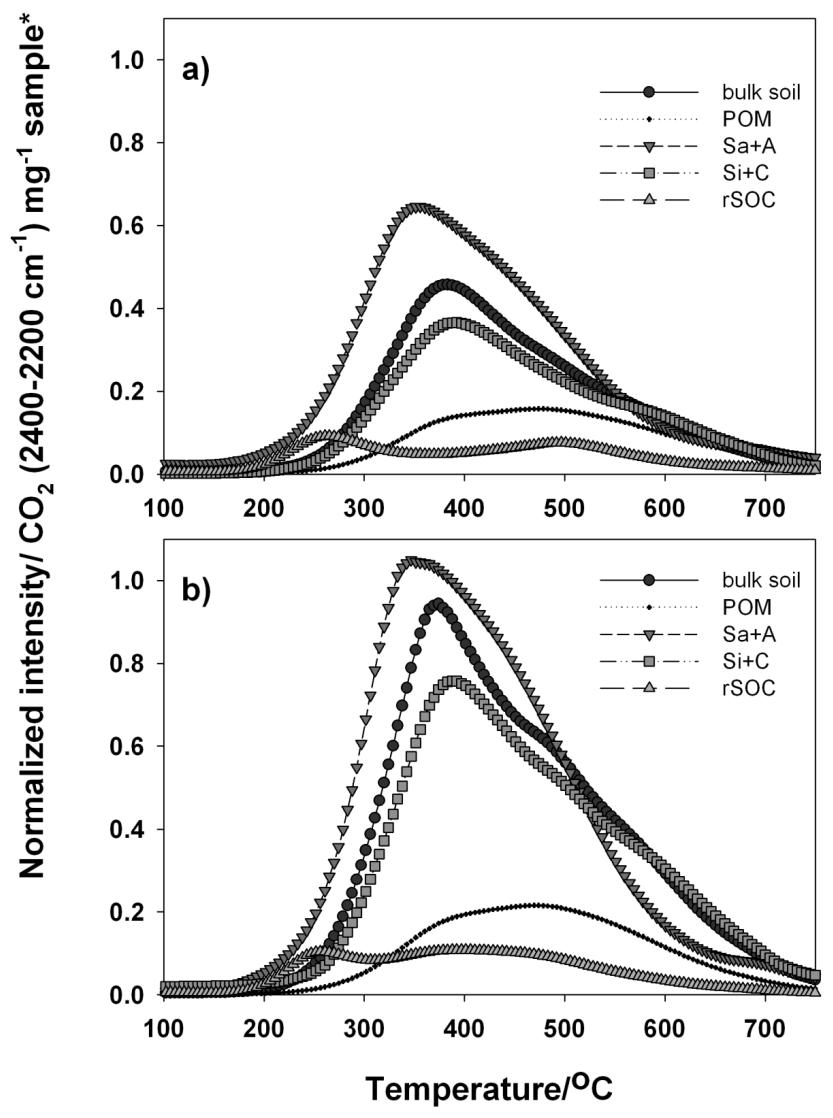

Fig. 7. FTIR-EGA $\mathrm{CO}_{2}$ thermograms of bulk soil and fractions heating from 25 to $700^{\circ} \mathrm{C}$ at $68^{\circ} \mathrm{C} \mathrm{min}^{-1}$ under synthetic air purge from the (a) Kraichgua and (b) Swabian Alb sites. Bulk soil $<2 \mathrm{~mm}$, POM-sand fraction $<1.8 \mathrm{~g} \mathrm{~cm}^{-3}$ fraction diluted $1: 50$ with preheated ball-milled quartz sand for thermal analysis., $\mathrm{Sa}+A$ sand fraction $>1.8 \mathrm{~g} \mathrm{~cm}^{-3}$, silt + clay $<63 \mu \mathrm{m}$, rSOC $<63 \mu \mathrm{m}$ treated with hot sodium hypochlorite. ${ }^{*}$ Normalized intensity is the integrated area of the $\mathrm{CO}_{2}$ peak from 2400 to $2200 \mathrm{~cm}^{-1}$ normalized to weight of the sample.

\subsection{Peak fitting of FTIR-EGA $\mathrm{CO}_{2}$ gas thermograms}

With the temperatures of maximum change of different functional groups as measured by in situ $T$ DRIFTS analyses as the first step for peak placement and determining the number of peaks followed by an examination of the shape of the evolved $\mathrm{CO}_{2}$ thermogram, a peak fitting of the FTIREGA $\mathrm{CO}_{2}$ gas profiles from bulk soils resulted in four different peaks or "fitted components" (Fig. 11). Component 1 corresponded to the decrease of the $\mathrm{C}-\mathrm{OH}$ vibration and the $\mathrm{C}-\mathrm{H}$ vibration. Component 2 was mainly the $\mathrm{C}-\mathrm{H}$ vibration, while component 3 was $-\mathrm{COO} / \mathrm{C}=\mathrm{C}$ vibrations. Finally, component 4 corresponded to $\mathrm{C}=\mathrm{C}$ vibration and also again $\mathrm{C}-\mathrm{OH}$ vibrations. The main effect in the $\mathrm{Bad}$ Lauchstädt experiment was seen between the two FYM treatments compared to the two without FYM (Table 5). The temperature of the center of the first component was at 298
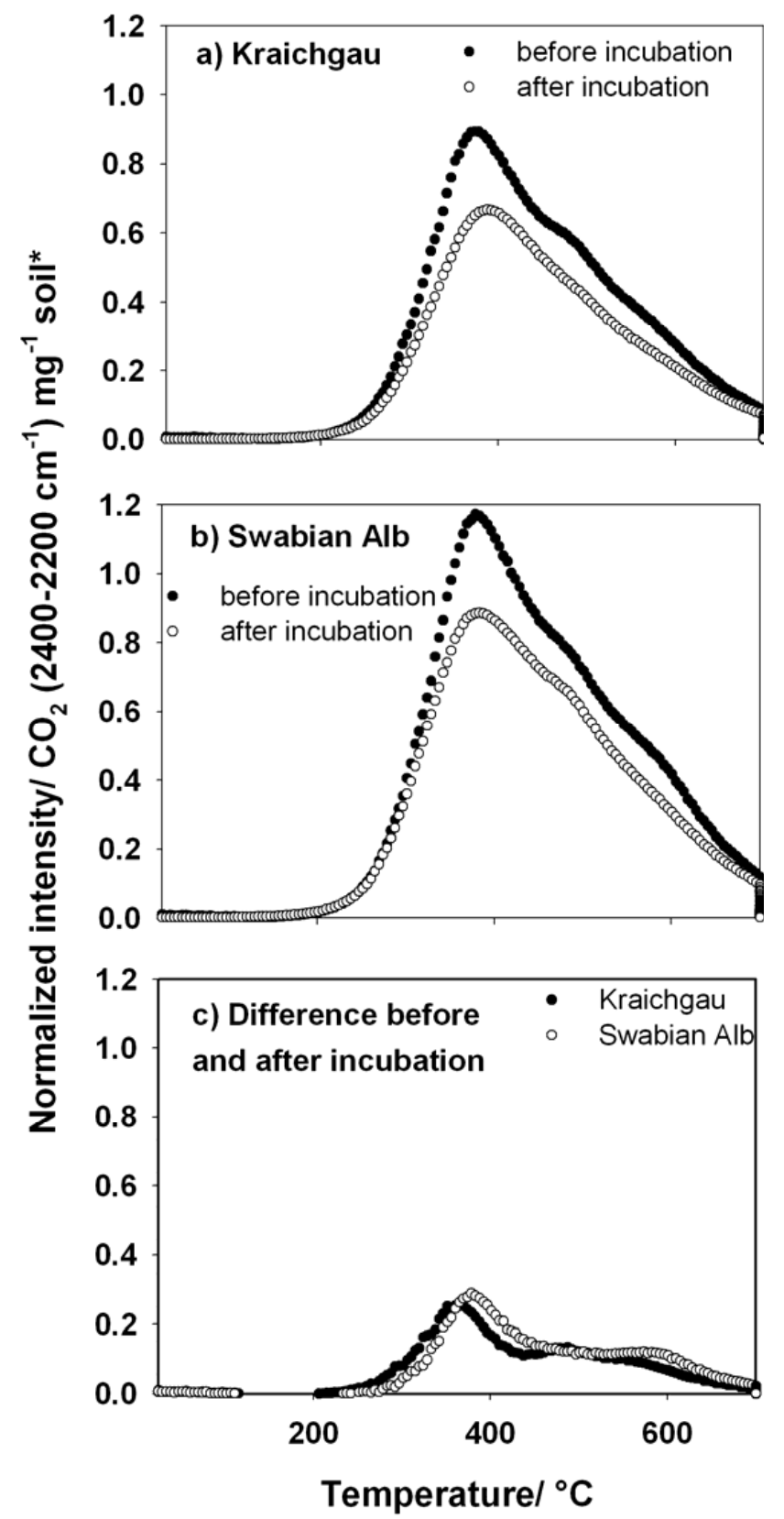

Fig. 8. Effects of 490 day incubation on thermally evolved $\mathrm{CO}_{2}$ thermogram. (A) Kraichgau soils, (B) Swabian soils, (C) difference when subtracting thermogram of soil at the end of incubation from thermogram at the beginning of the incubation. ${ }^{*}$ Normalized intensity is the integrated area of the $\mathrm{CO}_{2}$ peak from 2400 to $2200 \mathrm{~cm}^{-1}$ normalized to weight of the sample.

and $301{ }^{\circ} \mathrm{C}$ for FYM + NPK and FYM, respectively, while at 293 and $292{ }^{\circ} \mathrm{C}$ for NPK and CON, respectively. The relative contribution of fitted component 1 was similar between the treatments (3.3 to $4.2 \%$ ). Larger differences were found with components 2 and 4 between the treatments. For example, component 2 was representative of 25 and $23 \%$ of 


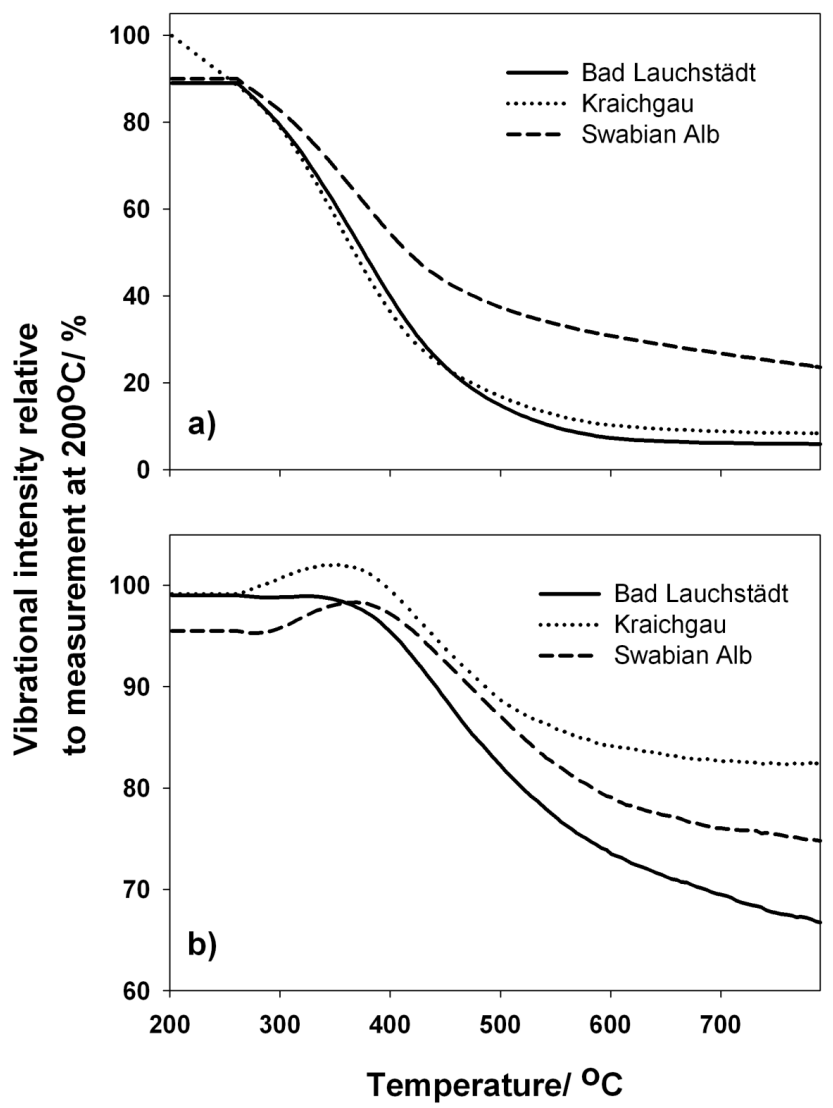

Fig. 9. In situ ${ }_{T}$ DRIFTS of bulk soil samples from Bad Lauchstädt, Kraichgau, and Swabian Alb of (a) C-H $\left(2930 \mathrm{~cm}^{-1}\right)$ vibrations and (b) $\mathrm{C}=\mathrm{O} / \mathrm{C}=\mathrm{C}\left(1620 \mathrm{~cm}^{-1}\right)$ vibrations.

the evolved $\mathrm{CO}_{2}$ for the FYM + NPK and FYM treatments compared to 18.8 and $18.6 \%$ in the non-FYM treatments. The opposite trend was seen with component 4 , and which was the largest pool, where the FYM treatments had a lower share (43.3 and $45.1 \%)$ compared to the non-FYM treatements $(49.1$ and $49.2 \%)$.

As with the measured $\mathrm{CO}_{2 \max }$, the center of each fitted component was at a slightly lower temperature in the Swabian Alb compared to the Kraichgau soils. Component 1 had a peak center at almost the same temperature in both soils (i.e., Kraichgau, $290^{\circ} \mathrm{C}$; Swabian Alb, $289^{\circ} \mathrm{C}$ ), but there was a nearly $10^{\circ} \mathrm{C}$ difference between the two sites regarding the second and third components. Component 2 in the Kraichgau had a peak center at $353{ }^{\circ} \mathrm{C}$ compared to $344^{\circ} \mathrm{C}$ in the Swabian Alb, while that of component 3 was at $445^{\circ} \mathrm{C}$ in the Kraichgau compared to $432{ }^{\circ} \mathrm{C}$ in the Swabian Alb. Again, a similar but smaller difference was found for component 4 with its center at $549^{\circ} \mathrm{C}$ in the Kraichgau soils compared to $541^{\circ} \mathrm{C}$ in the Swabian Alb soils. The largest contribution to the total $\mathrm{CO}_{2}$ evolution was provided by component 2 (35-46\%) for both soils. Component 1 was the smallest fraction, being slightly higher in Swabian Alb soils (4.7\%) compared to Kraichgau (3.4\%). Larger differences between sites

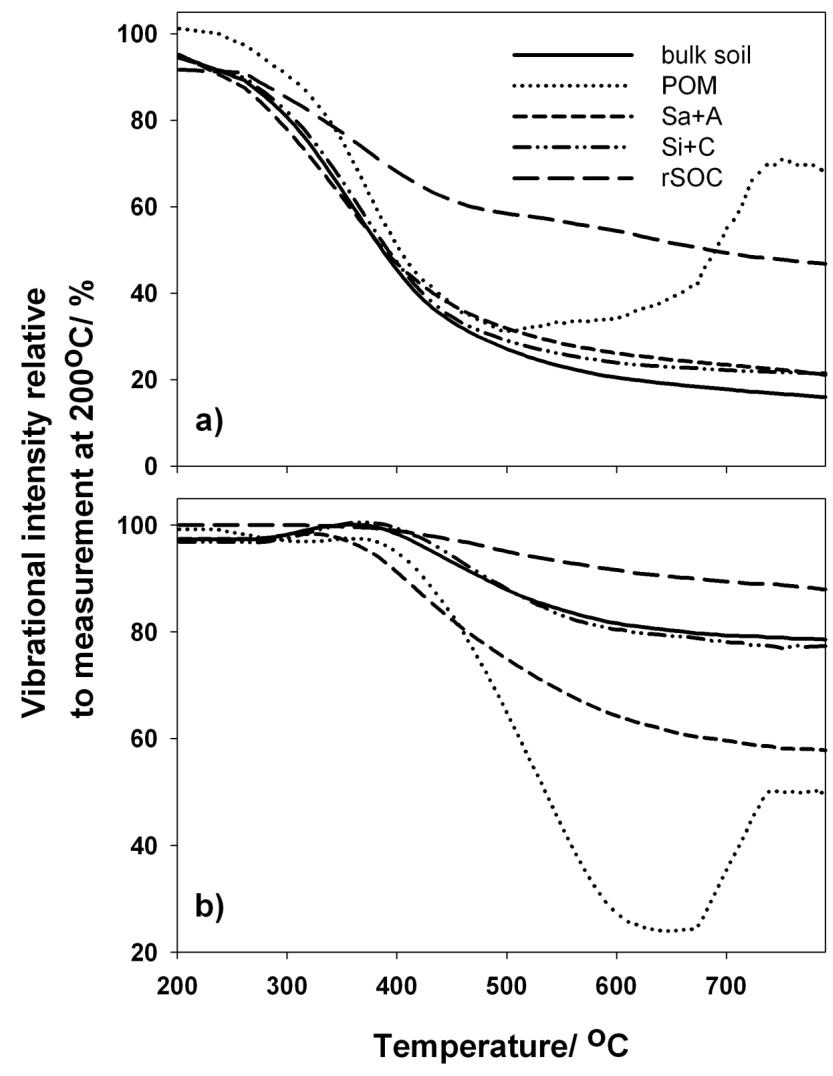

Fig. 10. In $\operatorname{situ}_{T}$ DRIFTS of the bulk soil and fractions of (a) C-H $\left(2930 \mathrm{~cm}^{-1}\right)$ vibrations and (b) $\mathrm{C}=\mathrm{O} / \mathrm{C}=\mathrm{C}\left(1620 \mathrm{~cm}^{-1}\right)$ vibrations. Average of Kraichgau and Swabian Alb sites.

were found for components 2 and 3 with 46 and $27.3 \%$ for the Kraichgau and 35 and $34 \%$ for the Swabian Alb. Lastly, component 4 was larger in the Swabian Alb at $26 \%$ compared to $23 \%$ in the Kraichgau.

\section{Discussion}

\subsection{Thermal stability of organic matter of soils and fractions}

Using the temperature of peak $\mathrm{CO}_{2}$ evolution as one indicator of thermal stability, the results from the three contrasting soils indicated that there may be a large portion of stable OM present in the Bad Lauchstädt soils given the large proportion of a high temperature component and its associative thermal behavior with aromatic-like structures. These findings are in agreement with what others have found during previous analyses of soils from Bad Lauchstädt by DTA and TGA (Leifeld et al., 2006), as well as pyrolysis-field ionization mass spectrometry methods (Leinweber and Schulten, 1993). This thermal stability may be due to the presence of very stable humus compounds formed within a Chernozem or the presence of black C (Eckmeier et al., 2007). 

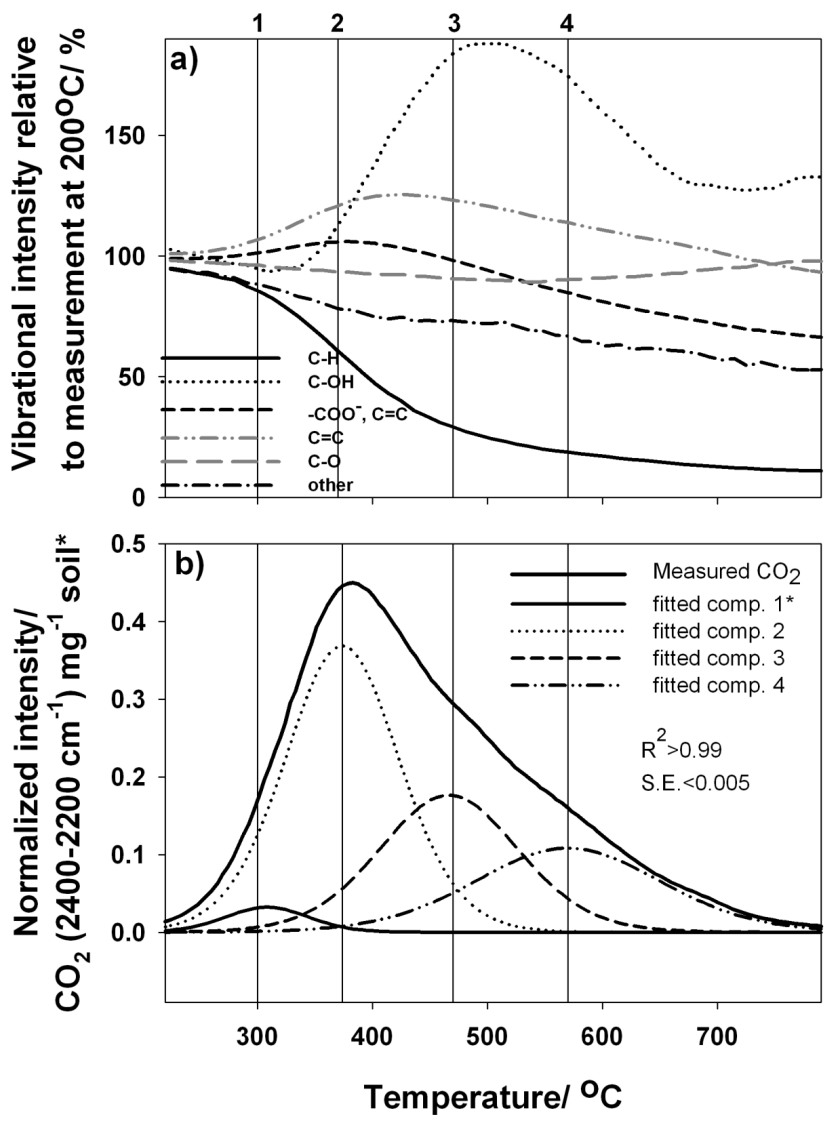

Fig. 11. Summary of qualitative changes in organic functional groups during heating as a guide to fitting components to quantitative evolved gas anlaysis: (a) in situ ${ }_{T}$ DRIFTS measurements of bulk soil from the Kraichgau site as a percentage of the vibrational intensity at $200^{\circ} \mathrm{C}$ to identify temperature of maximum change of functional groups. (b) Peak fitting with four components of evolved gas profile as measured by FTIR-EGA of bulk soil from Kraichgau site using previously identified temperatures of maximum change of functional groups. Statistics are from the goodness of fit of the four fitted components to the measured data. Reference lines 1 to 4 indicate the peak of the fitted components of the FTIR-EGA gas profile in Fig. 6b. * Normalized intensity is the integrated area of the $\mathrm{CO}_{2}$ peak from 2400 to $2200 \mathrm{~cm}^{-1}$ normalized to weight of the sample.

The effect of long-term manure application was evident in the FYM + NPK and FYM treatments of the Bad Lauchstädt soils with a relative enrichment of thermally labile substances as indicated by a lower temperature of $\mathrm{CO}_{2_{\max }}$. It has been shown previously that in the control treatment relative to the FYM + NPK treatment there is a relative enrichment of $\mathrm{C}$ in the clay, heavy density fractions, and of aromatic functional groups in the bulk soil via specific DRIFTS peak areas at the expense of the more labile fractions (Demyan, et al., 2012).

Further evidence of a link between FTIR-EGA results and dynamic changes of SOM quality was shown by the changes in thermal stability after 490 day incubation, which confirmed that ongoing microbial decomposition altered the thermal $\mathrm{CO}_{2}$ thermogram of the remaining SOM. Although, after a 490 day laboratory incubation experiment, the quality of lost $\mathrm{C}$ spanned the entire range of thermal stabilities, the maximum peak of $\mathrm{C}$ lost during incubation was slightly lower than the non-incubated soil $\mathrm{CO}_{2_{\max }}$. This indicated that the possible source of a large part of the respired $\mathrm{C}$ during incubation came from the $\mathrm{Si}+\mathrm{C}$ fraction, which was also the largest fraction by weight in the bulk soil, and also had a similar peak temperature as compared with the bulk soil. While the effect of the 490 day incubation did shift the $\mathrm{CO}_{2_{\max }}$ to a slightly higher temperature, the $\mathrm{C}$ loss was not confined to lower temperatures (below $350{ }^{\circ} \mathrm{C}$ ), but was also evolved at higher temperatures, indicating some apparently labile compounds easily decomposable to microorganisms are quite thermally resistant, as shown for the pure substances. Plante et al. (2011) also found that soils incubated for 588 days at $35^{\circ} \mathrm{C}$ have a higher thermal stability, as indicated by the temperature at which $50 \%$ of the mass loss or energy loss occurred measured via TG/DSC. Using the same $50 \%$ as threshold, but with evolved $\mathrm{CO}_{2}$ via FTIR-EGA, our results showed an increase from 433 to $442{ }^{\circ} \mathrm{C}$ after incubation. From these results, we could conclude that both $\mathrm{CO}_{2}$ max and $50 \%$ evolved $\mathrm{C}$ loss as measured by FTIR-EGA were indicators of the relative stability of SOM in these soils.

The thermal stability gradient of the SOM fractions did only partially follow their implied stabilities. There was a gradient in the mineral associated fractions tending from lower to higher thermal stability as shown by $\mathrm{CO}_{2 \max }$ in the order $\mathrm{Sa}+A<$ bulk soil $<\mathrm{Si}+\mathrm{C}$ but was not statistically different. The non-mineral associated POM did not fit into this relationship, as it had a higher peak temperature compared to the $\mathrm{Sa}+A, \mathrm{Si}+\mathrm{C}$ and bulk soil. As was shown with the pure substances, a high thermal stability was also found for components within xylan and tannic acid. These components are present in the form of hemicelluloses and polyphenols/lignins in relatively undecomposed plant residues having lost their labile compounds prior to sampling, as was the case with the analysed POM having been sampled seven months after last residue inputs. Dell'Abate et al. (2000) confirmed such changes in thermal stability during decomposition via DSC and TG measurements of compost in a 56 day incubation, observing an increase in the proportion of the higher temperature $\left(450^{\circ} \mathrm{C}\right)$ peak relative to the lower temperature peak $\left(300^{\circ} \mathrm{C}\right)$, indicating an enrichment in more thermally stabile humic substances. Others have also shown that there is a resistant POM fraction based on the size separation of $>100 \mu \mathrm{m}$ of $<1.8 \mathrm{~g} \mathrm{~cm}^{-3}$ being more labile and 100 to $53 \mu \mathrm{m}$ of $<1.8 \mathrm{~g} \mathrm{~cm}^{-3}$ being more stable (Cadisch et al., 1996). However, in our case this comparison may not be straightforward, as it was shown in this study that dilution with quartz sand changed the $\mathrm{CO}_{2_{\max }}$ of POM. A similar observation was made by Rovira et al. (2000) who observed that mineral interferences in the change of thermal 
stability of pure residues compared with residues mixed with red earth, even after subtracting the DSC curves of the unamended red earth from the DSC curves of the red earth mixed with residues.

Sodium hypochlorite $(\mathrm{NaOCl})$ is normally used to efficiently remove OM from soils and clays without greatly altering the clay mineral structure (Mikutta et al., 2005). Our FTIR-EGA results indicated that the $\mathrm{NaOCl}$ treatment has greatly altered the nature of the $\mathrm{Si}+\mathrm{C}$ fraction, as measured on the remaining residue ( $\mathrm{rSOC}$ ), so that a much less thermally stable peak evolved at relatively low temperature. This may have been the effect of the complete dispersion of any microaggregates and also exchange of organic substances from the clay minerals. It was surprising that this relatively thermally labile pool had survived oxidation by the $\mathrm{NaOCl}$. That may have been due to the fact that $\mathrm{NaOCl}$ does not completely attack aliphatic $\mathrm{C}$ compounds (Sleutel et al., 2009), which has been shown to have a lower thermal stability as compared to aromatic C (Schulten and Leinweber, 1999) and seems to lend evidence that physiochemical protection is playing a role in influencing the thermal stability of the $\mathrm{Si}+\mathrm{C}$ fraction. This was also shown qualitatively in our in situ $_{T}$ DRIFTS measurements of the bulk soils in which C$\mathrm{H}$ vibrations decreased rather rapidly and at an earlier temperature compared to $\mathrm{C}=\mathrm{C}$ vibrations. Due to the evident chemical alteration of the $\mathrm{rSOC}$ fraction by the $\mathrm{NaOCl}$ oxidation that has been used to isolate a supposedly very stable fraction, the thermal properties are greatly altered and this fraction may not be suitable for analysis by FTIR-EGA to infer biological stability.

\subsection{Allocation of thermally evolved carbon}

Using a novel approach of a peak fitting procedure, we were able to identify different "pools" of SOM with characteristic thermal signatures. This might lend evidence to link with functional properties such as used in SOM decomposition models. Through the peak fitting procedure, evolved $\mathrm{C}$, as measured by the FTIR-EGA, was allocated into several peaks or fitted components. Additional support for obtained pool allocation results were that the centroid or maximum of each fitted peak was consistent among the three sites and that these peaks coincided with different maximum or near maximum decreases in vibrational absorbances. As measured by in situ ${ }_{T}$ DRIFTS, there was an initial slight decline in C-O, $\mathrm{C}-\mathrm{OH}$, and $\mathrm{C}-\mathrm{H}$ vibrations, then a strong decrease in $\mathrm{C}-\mathrm{H}$ and continued decline in $\mathrm{C}-\mathrm{O}$ vibrations, and finally a decline in $\mathrm{C}=\mathrm{C}$, lending evidence to different organic compounds being decomposed at different temperatures. Three main trends were seen in the changing vibrational intensities over the heating experiment. First, at relatively low temperatures (200 to $300^{\circ} \mathrm{C}$ ) a decrease in intensity was found for the C-O and $\mathrm{C}-\mathrm{H}$ vibrations. This was evidence for the breakdown of aliphatic groups and also carbohydrates. Secondly, at slightly higher temperatures the rapid decrease of $\mathrm{C}-\mathrm{H}$ groups indi- cated the cracking of longer chained aliphatic compounds with an almost simultaneous increase in both $\mathrm{C}=\mathrm{O} / \mathrm{C}=\mathrm{C}$ and $\mathrm{C}=\mathrm{C}$ intensities. This clearly indicates the formation of secondary products such as more condensed aromatic structures, which was previously suggested during the heating under an inert atmosphere of brown coal (Murakami et al., 1997). Thirdly, there was a final decrease of both the $\mathrm{C}=\mathrm{O} / \mathrm{C}=\mathrm{C}$ and $\mathrm{C}=\mathrm{C}$ peaks at $>400^{\circ} \mathrm{C}$. The lower temperature at which the $\mathrm{C}=\mathrm{O} / \mathrm{C}=\mathrm{C}$ peak decreased relative to the $\mathrm{C}=\mathrm{C}$ peak showed decarboxylation happening before the breakdown of the aromatic structures, which was also found by Lu et al. (1997) via FTIR emission spectroscopy of humic substances. Kiem et al. (2000) found a similar stability or depletion sequence in comparisons of long-term managed fallow treatments compared with fertilized treatments using ${ }^{13} \mathrm{C}$ nuclear magnetic resonance and carbohydrate analysis. In the case of the increase in the "C-O" group at $2226 \mathrm{~cm}^{-1}$, this suggested the formation of nitriles as was earlier found in humic acid salts (Woelki and Salzer, 1995), as C $\equiv \mathrm{N}$ vibrations can also be present in this mid-infrared range. Additionally, via pyrolyis field ionization mass spectroscopy (PyFIMS), Sleutel et al. (2011) showed that at $<400^{\circ} \mathrm{C}$ combustion products are relatively enriched in lipids, carbohydrates, and peptides compared to $>400^{\circ} \mathrm{C}$ where there was a greater proportion of alkyl-aromatics. Other previous work on Py-FIMS led to the general molecular framework of three thermal classes: (i) unbound undecomposed plant fragments relatively rich in aliphatics; (ii) a thermally labile fraction containing N-containing compounds and carbohydrates associated with humified OM; and (iii) thermally stable mineral bound OM (Schulten and Leinweber, 1999). In the soils of the Bad Lauchstädt experiment, Mertz et al. (2005) found in the coarse clay fractions a general increase of thermal stability of pyrolyis compounds after $98 \mathrm{yr}$ of fertilizer deprivation compared to the full fertilized treatment, which complements our results of increased thermal stability of the bulk soil in the CON treatment relative to the FYM + NPK treatment. In our experiment, the peak fitting results also showed an enrichment in the most thermally stable compounds in the non-FYM treatments as compared to the FYM-treatments.

In the current study, the larger percentage of fitted component 1 in the Swabian Alb compared to the Kraichgau may be related to the slightly larger portion of labile $\mathrm{C}$ in the Swabian Alb site as measured by extractible $\mathrm{C}$ and microbial biomass. Additionally, the larger percentage in the most thermally stable component, the 4th component, in the Swabian Alb may have been a result of the higher clay content of the Swabian Alb compared to the Kraichgau soils. Further vibrational functional groups may be of interest and related to $\mathrm{OM}$, but in our study it was found that the absorbance values of the wavenumbers $<1000 \mathrm{~cm}^{-1}$ where there is a strong influence of mineral vibrations (Nguyen et al., 1991) increased during the entire heating procedure or were highly variable from one scan to the next, complicating interpretation. As the studied vibrational frequencies were selected based on 
the fact that they represent mostly organic and not mineral functional groups (Demyan et al., 2012), any changes in absorbance intensity due to mineralogical changes especially $>540^{\circ} \mathrm{C}$ should have been avoided. This combined use of both in situ $_{T}$ DRIFTS and FTIR-EGA information to assign evolved $\mathrm{CO}_{2}$ of different temperature intervals to different qualities of organic matter is a promising and new step towards application of this method.

\subsection{Specific considerations using FTIR-EGA thermal approaches}

Several conditions must be met to obtain satisfactory FTIREGA results. First, a major drawback in oxidative thermal combustion reactions is the potential of formation of secondary reactions, e.g., charring, during the heating process. It is thus important to set up experimental conditions with minimal interference from such secondary reactions. Our tests showed that low heating rates favored formation of secondary reactions. We therefore identified $68{ }^{\circ} \mathrm{C} \mathrm{min}^{-1}$ as the optimal heating rate for soils for our system to balance the need for reproducible heating rate and also minimize secondary reactions. This heating rate is similar to the $70^{\circ} \mathrm{C} \mathrm{min}^{-1}$ used in pyrolysis-field ionization mass spectrometry (Py-FIMS) experiments by Schulten and Leinweber (1993). This may also have led to the occurrence of only one $\mathrm{CO}_{2}$ peak for the bulk soils as opposed to traditional TGA or DSC profiles which even for bulk soils usually show two distinct peaks of OM associated weight loss (Dell'Abate et al., 2003). A possible reason for the lack of additional peaks is that we used a much higher heating rate $\left(68^{\circ} \mathrm{C} \mathrm{min}^{-1}\right)$ compared to other studies (Siewert, 2004; Plante et al., 2011; Leinweber et al., 1992), which used a rate of $10-30{ }^{\circ} \mathrm{C} \mathrm{min}^{-1}$ and therefore may have been subject to more charring effects.

Secondly, the amount of potential $\mathrm{CO}_{2}$ evolution will determine the experimental conditions used during analysis. In our case a $\mathrm{C}$ content of $>2.5 \mathrm{mg}$ in the sample cup resulted in absorbances of $>2.5$ A.U. which were no longer linear relative to $\mathrm{C}$ concentration.

Thirdly, the combustion conditions should be similar among the tested materials. This is particularly true for material with high OC content. In the case of POM and the organic standards (e.g., glucose, xylan, tannic acid), the $\mathrm{CO}_{2}$ evolution profiles were changed by diluting a sample with pre-heated quartz sand. This may have been the consequence of increasing the aeration within the sample and also changing its heat conductivity compared to a pure sample. It has been suggested that secondary reactions such as charring are present during combustion of cellulose, hemicellulose, and tannic acid (Court et al., 2009). As these secondary reactions do not necessarily reflect the thermal stability of the compound but are rather a result of the heating procedure, care must be taken in interpreting the thermal characteristics of high OC content substances. For the current experimental setup, we propose that for non-mineral samples (POM, organic soils, plant samples) a dilution with inert material (quartz sand) is beneficial in replicating the thermal conditions of mineral soils and fractions. This will reduce charring and standardize the aeration and thermal conductivity of the sample, which is important at high heating rates.

\section{Conclusion}

Linking a high temperature thermal reaction chamber with a FTIR gas cell was shown to be able to quantify evolved gas $\left(\mathrm{CO}_{2}\right)$ in order to characterize SOM of different soils and SOM fractions. The conditions for an optimized FTIREGA procedure were (1) the use of a standard with well known thermal decomposition reaction (i.e., $\mathrm{NaHCO}_{3}$ ) to quantify mid-infrared absorbance units to $\mathrm{CO}_{2}$ production and to identify the optimal purge and scan rates, which for our $136 \mathrm{~mL}$ gas cell were $15 \mathrm{~L} \mathrm{~h}^{-1}$ synthetic air purge with a scan every $4 \mathrm{~s}$; (2) a rapid heating rate $\left(68^{\circ} \mathrm{C} \mathrm{min}^{-1}\right)$ to minimize char formation; and (3) a dilution of high $\mathrm{C}$ content samples, especially POM and plant samples, for similar heating conditions in the heating chamber as compared to mineral soils. The amount and shape of evolved $\mathrm{CO}_{2}$ under an oxidizing atmosphere evolved from 25 to $700^{\circ} \mathrm{C}$, depending on the chemical composition (e.g., simple C-C bonding of glucose compared to complex ring structure of tannic acid), type of soil (e.g., Chernozem versus Cambisol) and also fraction of soil investigated (e.g., silt and clay fraction versus bulk soil versus POM). Temperature-dependent changes in the intensity of mid-infrared molecular vibrations also indicated different $\mathrm{OM}$ compounds decomposing at different temperatures.

In a novel approach, a peak fitting procedure based on changes of molecular vibrations derived from situ ${ }_{T}$ DRIFTS measurements was used to allocate $\mathrm{C}$ evolved at different temperature into separate $\mathrm{C}$ pools of inferred stability. The in situ ${ }_{T}$ DRIFTS results gave evidence of different $\mathrm{C}$ components (i.e., $\mathrm{C}-\mathrm{OH}=$ unknown $\mathrm{C}$ vibration $<\mathrm{C}-\mathrm{H}<-\mathrm{COO}$ and $\mathrm{C}=\mathrm{C}<\mathrm{C}=\mathrm{C}$ ) being evolved at different times during the 220 to $700^{\circ} \mathrm{C}$, which justified and lent a quality aspect to the curve fitting procedure for the FTIR-EGA evolved $\mathrm{CO}_{2}$. A combination of the FTIR-EGA and in situ ${ }_{T}$ DRIFTS methods clearly provide an improved approach for SOM characterization. Even though analysis of soils with different clay mineralogies and land use types is needed to test the applicability of this method to different soils and land uses, the current results prove that the combined use of FTIR-EGA and in situ $u_{T}$ DRIFTS provides a good theoretical molecular basis and a major step forward for the fitting of different components to the evolved gas thermogram.

\section{Supplementary material related to this article is available online at: http://www.biogeosciences.net/10/ 2897/2013/bg-10-2897-2013-supplement.pdf.}


Acknowledgements. This scientific research was supported by the Deutsche Forschungsgemeinschaft (DFG) as part of the Research Unit "Agricultural Landscapes under Global Climate Change Processes and Feedbacks on a Regional Scale (FOR 1695)" and PAK Project 346, "Structure and Functions of Agricultural Landscapes under Global Climate Change-Processes and Projections on a Regional Scale" within subproject P3. Additionally, the authors would like to thank S. Becker-Fazekas for help during FTIR-EGA method testing, and A. Rager and A. Schmidt from Bruker Optik GmbH for extensive technical support during method development. We would also like to thank A. Plante, S. Sleutel, and one anonymous review for comments on an earlier version of this paper.

Edited by: F. Carswell

\section{References}

Anderson, J. U.: An improved pretreatment for mineralogical analyses of samples containing organic matter, Clay. Clay Miner., 10, 380-388, 1963.

Anderson, J. P. E. and Domsch, K. H.: A physiological method for the quantitative measurement of microbial biomass in soils, Soil Biol. Biochem., 10, 215-221, 1978.

Baldry, P. J., Cullis, C. F., Goring, D., and Hirschler, M. M.: The combustion of cigarette paper, Fire Mater., 12, 25-33, 1988.

Blumstein, A.: Polymerization of adsorbed monolayers. II. Thermal degradation of the inserted polymer, J. Polym. Sci. Part A, 3, 2665-2672, 1965.

Cadisch, G., Imhof, H., Urquiaga, S., Boddey, R. M., and Giller, K. E.: Carbon turnover $\left(\delta^{13} \mathrm{C}\right)$ and nitrogen mineralization potential of particulate light soil organic matter after rainforest clearing, Soil Biol. Biochem., 28, 1555-1567, 1996.

Conzen, J.: Multivariate Calibration, A practical guide for developing methods in the quantitative analytical chemistry, Bruker Optik GmbH, Germany, 2003.

Court, R. W. and Sephton, M. A.: Quantitative flash pyrolysis Fourier transform infrared spectroscopy of organic materials, Anal. Chim. Acta, 639, 62-66, 2009.

Dell'Abate, M. T., Benedetti, A., and Sequi, P.: Thermal methods of organic matter maturation monitoring during a composting process, J. Therm. Anal. Calorim., 61, 389-396, 2000.

Dell'Abate, M. T., Benedetti, A., and Brookes, P. C.: Hyphenated techniques of thermal analysis for characterisation of soil humic substances, J. Sep. Sci., 26, 433-440, 2003.

Demyan, M. S., Rasche, F., Schulz, E., Breulmann, M., Müller, T., and Cadisch, G.: Use of specific peaks obtained by diffuse reflectance Fourier transform mid-infrared spectroscopy to study the composition of organic matter in a Haplic Chernozem, Eur. J. Soil Sci., 63, 189-199, 2012.

Dorodnikov, M., Fangmeier, A., and Kuzyakov, Y.: Thermal stability of soil organic matter pools and their $\delta^{13} \mathrm{C}$ values after $\mathrm{C} 3-\mathrm{C} 4$ vegetation change, Soil Biol. Biochem., 39, 1173-1180, 2007.

Dorodnikov, M., Fangmeier, A., Giesemann, A., Weigel, H., Stahr, K., and Kuzyakov, Y.: Thermal stability of soil organic matter pools and their turnover times calculated by $\delta^{13} \mathrm{C}$ under elevated $\mathrm{CO}_{2}$ and two levels of $\mathrm{N}$ fertilisation, Isot. Environ. Healt. S., 44, 365-376, 2008.
Dreibrodt, S., Kleber, M., and Jahn, R.: Das Mineralinventar der Versuchsfläche "Statischer Dauerdüngungsversuch v120, Bad lauchstädt", Arch. Acker. Pfl. Boden, 48, 227-240, 2002.

Eckmeier, E., Gerlach, R., Gehrt, E., and Schmidt, M. W. I.: Pedogenesis of Chernozems in Central Europe - A review, Geoderma, 139, 288-299, 2007.

Fernández, J., Plante, A., Leifeld, J., and Rasmussen, C.: Methodological considerations for using thermal analysis in the characterization of soil organic matter, J. Therm. Anal. Calorim., 104, 389-398, 2011.

Fernández, J. M., Peltre, C., Craine, J. M., and Plante, A. F.: Improved characterization of soil organic matter by thermal analysis using $\mathrm{CO}_{2} / \mathrm{H}_{2} \mathrm{O}$ evolved gas analysis, Environ. Sci. Technol., 46, 8921-8927, 2012.

Gaál, F., Szöllosy, I., Arnold, M., and Paulik, F.: Determination of the organic matter, metal carbonate and mobile water in soils simultaneous TG, DTG, DTA and EGA techniques, J. Therm. Anal., 42, 1007-1016, 1994.

Harris, D., Horwáth, W. R., and Van Kessel, C.: Acid fumigation of soils to remove carbonates prior to total organic carbon or carbon-13 isotopic analysis, Soil Sci. Soc. Am. J., 65, 18531856, 2001.

Haselsteiner, T., Erbel, C., Kunze, C., and Spliethoff, H.: An in situ optical gas phase analysis approach for TGA: Its assessment and application, Appl. Energy, 88, 5200-5207, 2011.

Helfrich, M., Flessa, H., Dreves, A., and Ludwig, B.: Is thermal oxidation at different temperatures suitable to isolate soil organic carbon fractions with different turnover?, J. Plant Nutr. Soil Sc., 173, 61-66, 2010.

IUSS Working Group WRB: World Reference Base for Soil Resources 2006, first update 2007, World Soil Resources Reports, FAO, Rome, 2007.

Janković, B.: Kinetic analysis of isothermal decomposition process of sodium bicarbonate using the weibull probability functionestimation of density distribution functions of the apparent activation energies, Metall Mater Trans B, 40, 712-726, 2009.

Kiem, R., Knicker, H., Körschens, M., and Kögel-Knabner, I.: Refractory organic carbon in C-depleted arable soils, as studied by ${ }^{13} \mathrm{C}$ NMR spectroscopy and carbohydrate analysis, Org. Geochem., 31, 655-668, 2000.

Körschens, M., Stegemann, K., Pfefferkorn, A., Weise, V., and Müller, A.: Der Statische Düngungsversuch Bad Lauchstädt nach 90 Jahren, Einfluß der Düngung auf Boden, Pflanze und Umwelt, Stuttgart: B. G. Teubner Verlagsgesellschaft, 1994.

Leifeld, J., Franko, U., and Schulz, E.: Thermal stability responses of soil organic matter to long-term fertilization practices, Biogeosciences, 3, 371-374, doi:10.5194/bg-3-371-2006, 2006.

Leinweber, P. and Schulten, H.: Dynamics of soil organic matter studied by pyrolysis - field ionization mass spectrometry, J. Anal. Appl. Pyrol., 25, 123-136, 1993.

Leinweber, P., Schulten, H., and Horte, C.: Differential thermal analysis, thermogravimetry and pyrolysis-field ionisation mass spectrometry of soil organic matter in particle-size fractions and bulk soil samples, Thermochim. Acta, 194, 175-187, 1992.

Lopez-Capel, E., Sohi, S. P., Gaunt, J. L., and Manning, D. A. C.: Use of thermogravimetry-differential scanning calorimetry to characterize modelable soil organic matter fractions, Soil Sci. Soc. Am. J., 69, 136-140, 2005. 
Lu, X. Q., Vassallo, A. M., and Johnson, W. D.: Thermal stability of humic substances and their metal forms: An investigation using FTIR emission spectroscopy, J. Anal. Appl. Pyrol., 43, 103-114, 1997.

Mertz, C., Kleber, M., and Jahn, R.: Soil organic matter stabilization pathways in clay sub-fractions from a time series of fertilizer deprivation, Org. Geochem., 36, 1311-1322, 2005.

Mikutta, R., Kleber, M., Kaiser, K., and Jahn, R.: Review: Organic Matter Removal from Soils using Hydrogen Peroxide, Sodium Hypochlorite, and Disodium Peroxodisulfate, Soil Sci. Soc. Am. J., 69, 120-135, 2005.

Murakami, K., Shirato, H., and Nishiyama, Y.: In situ infrared spectroscopic study of the effects of exchanged cations on thermal decomposition of a brown coal, Fuel, 76, 655-661, 1997.

Mittleman, M.: Quantitative TG/IR, Thermochim. Acta, 166, 301308, 1990.

Nguyen, T. T., Janik, L. J., and Raupach, M.: Diffuse reflectance infrared Fourier transform (DRIFT) spectroscopy in soil studies, Aust. J. Soil Res., 29, 49-67, 1991.

Pansu, M. and Gautheyrou, J.: Handbook of Soil Analysis. Mineralogical, Organic and Inorganic Methods, Springer Verlag Berlin Heidelberg, the Netherlands, 2006.

Plante, A. F., Fernández, J. M., and Leifeld, J.: Application of thermal analysis techniques in soil science, Geoderma, 153, 1-10, 2009.

Plante, A. F., Fernández, J. M., Haddix, M. L., Steinweg, J. M., and Conant, R. T.: Biological, chemical and thermal indices of soil organic matter stability in four grassland soils, Soil Biol. Biochem., 43, 1051-1058, 2011.

Rovira, P. and Vallejo, V. R.: Examination of thermal and acid hydrolysis procedures in characterization of soil organic matter, Commun. Soil Sci. Plan., 31, 81-100, 2000.

Schlichting, E., Blume, H. P., and Stahr, K.: Bodenkundliches Praktikum., Blackwell Wissenschafts-Verlag, Berlin, Vienna, 1995.

Schulten, H. and Leinweber, P.: Pyrolysis-field ionization mass spectrometry of agricultural soils and humic substances: Effect of cropping systems and influence of the mineral matrix, Plant Soil, 151, 77-90, 1993.
Schulten, H. and Leinweber, P.: Thermal stability and composition of mineral-bound organic matter in density fractions of soil, Eur. J. Soil Sci., 50, 237-248, 1999.

Siewert, C.: Rapid screening of soil properties using thermogravimetry, Soil Sci. Soc. Am. J., 68, 1656-1661, 2004.

Sleutel, S., Leinweber, P., Ara Begum, S., Kader, M. A., and De Neve, S.: Shifts in soil organic matter composition following treatment with sodium hypochlorite and hydrofluoric acid, Geoderma, 149, 257-266, 2009.

Sleutel, S., Leinweber, P., Van Ranst, E., Kader, M. A., and Jegajeevagan, K.: Organic matter in clay density fractions from sandy cropland soils with differing land-use history, Soil Sci. Soc. Am. J., 75, 521-532, 2011.

Toops, T. J., Smith, D. B., and Partridge, W. P.: Quantification of the in situ DRIFT spectra of $\mathrm{Pt} / \mathrm{K} / \gamma-\mathrm{A} 12 \mathrm{O} 3 \mathrm{NO}_{\mathrm{x}}$ adsorber catalysts, Appl. Catal., 58, 245-254, 2005.

von Lützow, M., Kögel-Knabner, I., Ekschmitt, K., Flessa, H., Guggenberger, G., Matzner, E., and Marschner, B.: SOM fractionation methods: Relevance to functional pools and to stabilization mechanisms, Soil Biol. Biochem., 39, 2183-2207, 2007.

von Lützow, M., Kögel-Knabner, I., Ludwig, B., Matzner, E., Flessa, H., Ekschmitt, K., Guggenberger, G., Marschner, B., and Kalbitz, K.: Stabilization mechanisms of organic matter in four temperate soils: Development and application of a conceptual model, J. Plant Nutr. Soil Sc., 171, 111-124, 2008.

Woelki, G. and Salzer, R.: Thermal investigations of the structure of two humic acid salts by in situ FTIR spectroscopy, Fresen. J. Anal. Chem., 352, 529-531, 1995.

Zimmermann, M., Leifeld, J., Abiven, S., Schmidt, M. W. I., and Fuhrer, J.: Sodium hypochlorite separates an older soil organic matter fraction than acid hydrolysis, Geoderma, 139, 171-179, 2007a.

Zimmermann, M., Leifeld, J., and Fuhrer, J.: Quantifying soil organic carbon fractions by infrared-spectroscopy, Soil Biol. Biochem., 39, 224-231, 2007b. 